\title{
Modeling chemistry in and above snow at Summit, Greenland - Part 1: Model description and results
}

\author{
J. L. Thomas ${ }^{1, *}$, J. Stutz ${ }^{1}$, B. Lefer ${ }^{2}$, L. G. Huey ${ }^{3}$, K. Toyota ${ }^{4,5}$, J. E. Dibb ${ }^{6}$, and R. von Glasow ${ }^{7}$ \\ ${ }^{1}$ University of California, Department of Atmospheric and Oceanic Sciences, Los Angeles, CA, USA \\ ${ }^{2}$ Earth and Atmospheric Sciences Department, University of Houston, Houston, TX, USA \\ ${ }^{3}$ School of Earth and Atmospheric Sciences, Georgia Institute of Technology, Atlanta, Georgia, USA \\ ${ }^{4}$ Department of Earth and Space Science and Engineering, York University, Toronto, Ontario, Canada \\ ${ }^{5}$ Air Quality Research Division, Science and Technology Branch, Environment Canada, Toronto, Ontario, Canada \\ ${ }^{6}$ Institute for the Study of Earth, Oceans and Space, University of New Hampshire, Durham, New Hampshire, USA \\ ${ }^{7}$ School of Environmental Sciences, University of East Anglia, Norwich, UK \\ *now at: UPMC Univ. Paris 06, Université Versailles St-Quentin, CNRS/INSU, UMR 8190, LATMOS-IPSL, Paris, France
}

Received: 1 December 2010 - Published in Atmos. Chem. Phys. Discuss.: 21 December 2010

Revised: 11 May 2011 - Accepted: 12 May 2011 - Published: 26 May 2011

\begin{abstract}
Sun-lit snow is increasingly recognized as a chemical reactor that plays an active role in uptake, transformation, and release of atmospheric trace gases. Snow is known to influence boundary layer air on a local scale, and given the large global surface coverage of snow may also be significant on regional and global scales. We present a new detailed one-dimensional snow chemistry module that has been coupled to the 1-D atmospheric boundary layer model MISTRA. The new 1-D snow module, which is dynamically coupled to the overlaying atmospheric model, includes heat transport in the snowpack, molecular diffusion, and wind pumping of gases in the interstitial air. The model includes gas phase chemical reactions both in the interstitial air and the atmosphere. Heterogeneous and multiphase chemistry on atmospheric aerosol is considered explicitly. The chemical interaction of interstitial air with snow grains is simulated assuming chemistry in a liquid-like layer (LLL) on the grain surface. The coupled model, referred to as MISTRA-SNOW, was used to investigate snow as the source of nitrogen oxides $\left(\mathrm{NO}_{\mathrm{x}}\right)$ and gas phase reactive bromine in the atmospheric boundary layer in the remote snow covered Arctic (over the Greenland ice sheet) as well as to investigate the link between halogen cycling and ozone depletion that has been observed in interstitial air. The model is validated using data taken 10 June-13 June, 2008 as part of the Greenland Sum-
\end{abstract}

mit Halogen- $\mathrm{HO}_{\mathrm{x}}$ experiment (GSHOX). The model predicts that reactions involving bromide and nitrate impurities in the surface snow can sustain atmospheric $\mathrm{NO}$ and $\mathrm{BrO}$ mixing ratios measured at Summit, Greenland during this period.

\section{Introduction}

The significance of chemistry in surface snow and on ice was first discussed in the context of boundary layer ozone depletion events in the coastal Arctic during spring (Hausmann and Platt, 1994; Barrie et al., 1988; Foster et al., 2001). This ozone loss has been attributed to catalytic destruction of ozone by bromine released from frost flowers, open leads, first year sea ice, or recycling on aerosol (e.g. Hausmann and Platt, 1994; Barrie et al., 1988; Foster et al., 2001; Simpson et al., 2007b; Kaleschke et al., 2004; Kalnajs and Avallone, 2006; Simpson et al., 2007a; Piot and von Glasow, 2008; Zhao et al., 2008). At Summit (in the center of the Greenland ice sheet), where the total bromine loading is lower than in coastal regions, it has been hypothesized that active bromine chemistry may also occur and alter $\mathrm{HO}_{\mathrm{x}}$ partitioning towards $\mathrm{OH}$, increasing the oxidative capacity of the atmosphere (Peterson and Honrath, 2001; Sjostedt et al., 2007; Chen et al., 2007).

Correspondence to: J. L. Thomas

(jennie.thomas@latmos.ipsl.fr)

Published by Copernicus Publications on behalf of the European Geosciences Union. 
Snow-covered regions are also known to produce nitrogen oxides $\left(\mathrm{NO}_{\mathrm{x}}=\mathrm{NO}+\mathrm{NO}_{2}\right)$ in the snowpack (e.g. Honrath et al., 1999, 2000, 2002; Jones et al., 2000; Davis et al., 2001; Dibb et al., 2002; Jacobi et al., 2004). Vertical gradients of $\mathrm{NO}_{\mathrm{x}}$ and $\mathrm{HNO}_{3}$ during summer 2000 (Honrath et al., 2002) as well as shading experiments and measurements of gases in interstitial air (Jacobi et al., 2004) suggest a photochemical $\mathrm{NO}_{\mathrm{x}}$ source in the surface snow.

Recent laboratory experiments show that $\mathrm{OH}$ produced from nitrate at the surface of frozen ice reacts with bromide to form gas phase bromine with high efficiency (Abbatt et al., 2010). This suggests that nitrate is an oxidant that contributes to halogen activation and release at the surface of snow grains. Earlier work by George and Anastasio (2007) showed that photolysis of solutions containing bromide and either nitrate or $\mathrm{H}_{2} \mathrm{O}_{2}$ formed gaseous bromine via photochemistry and that the production was dependent on $\mathrm{pH}$. The production of $\mathrm{OH}$ at ice surfaces from both $\mathrm{H}_{2} \mathrm{O}_{2}$ and $\mathrm{NO}_{3}^{-}$ has also been demonstrated by Chu and Anastasio (2003). The interplay between nitrate and bromide photochemistry has recently also been studied in thin water films (Richards et al., 2011). In addition to these laboratory and theoretical studies, the motivation for our model comes from indirect evidence for halogen chemistry at Summit (Sjostedt et al., 2007) and direct evidence for $\mathrm{NO}_{\mathrm{x}}$ in the boundary layer resulting from snowpack chemistry (e.g. Jacobi et al., 2004; Jacobi and Hilker, 2007).

Model work on nitrate photolysis occurring in a liquid-like layer on snow grains has suggested $\mathrm{NO}_{3}^{-}$in snow is the most likely source of $\mathrm{NO}_{\mathrm{x}}$ in the atmosphere above remote, snow covered regions (Jacobi and Hilker, 2007; Boxe and SaizLopez, 2008; Bock and Jacobi, 2010). HONO release from the remote snowpack has been measured in the Arctic (Zhou et al., 2001; Dibb et al., 2002; Honrath et al., 2002) and recent model work suggesting $\mathrm{HONO}$ is formed from $\mathrm{NO}_{2}^{-}$on the surface of snow grains, followed by transfer to the interstitial air and mixing upwards via wind pumping was presented by Liao and Tan (2008).

Despite numerous observations demonstrating the importance of snow photochemistry, our quantitative understanding of the chemistry in the coupled snow, firn (snow that has been left over from past seasons), and atmosphere system is poor. Based on field and laboratory observations as well as modeling studies of snow physics and chemistry an initial picture of the mechanisms controlling this highly coupled system has emerged, shown in Fig. 1 (Domine and Shepson, 2002; Grannas et al., 2007; Domine et al., 2008). Well known tropospheric photochemistry of $\mathrm{HO}_{\mathrm{x}}, \mathrm{NO}_{\mathrm{x}}$, VOCs, and ozone occurs over snow covered surfaces. Reactive halogen chemistry also plays an important role in many environments and evidence for reactive halogen chemistry at Summit during 2007 and 2008 is presented by Stutz et al. (2011), Thomas et al. (2011); Brooks et al. (2011); Liao et al. (2011); Haman et al. (2011); and Dibb et al. (2010).

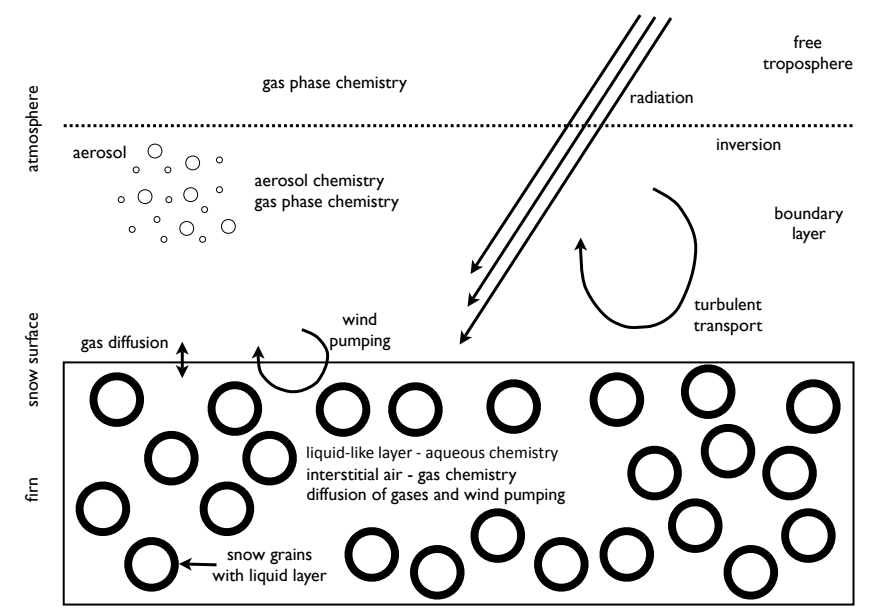

Fig. 1. Schematic depiction of the most important local processes controlling the atmospheric composition over sunlit snow. These processes are also included in the one-dimensional boundary layer model MISTRA-SNOW, where gas phase chemistry is calculated in all layers, aerosol chemistry is included in the boundary layer, and snow LLL chemistry is included below the snow surface.

Vertical mixing and boundary layer evolution are important because they can modulate surface trace gas concentrations. Due to the particular properties of snow, i.e. low temperatures and high albedo, boundary layers can become very shallow during times of low and absent sun, i.e. during night or winter. A successful model description has to include the boundary layer evolution and related mixing processes in order to correctly model observed atmospheric mixing ratios. Observations of chemistry over snow and ice have resulted in increasing interest in the boundary layer processes that govern exchanges between the snow surface and the atmosphere. A recent review by Anderson and Neff (2008) provides an excellent overview of these processes in polar regions.

The strong influence of snow photochemistry on the overlying air is partly because snow is a highly porous medium. Interstitial air occupies approximately $70 \%$ of the snow volume and is efficiently exchanged with the overlying atmosphere through gas diffusion and wind pumping. Gases in the interstitial air undergo gas phase chemical reactions and because of the high ice surface to interstitial air volume ratio the air composition is highly dependent on heterogeneous/multiphase chemistry on ice surfaces. These processes are often driven by solar radiation making snow interstitial air a unique coupled physical-chemical system. Two recent papers (Grannas et al., 2007; Domine et al., 2008) have reviewed these processes and have called for new photochemical models of snow that are based on a detailed description of snow chemistry and its coupling to the atmosphere.

The development of the coupled model (MISTRASNOW) was motivated by the desire to explain previously observed elevated levels of $\mathrm{NO}_{\mathrm{x}}$ at Summit, Greenland, as 
well as new measurements of $\mathrm{NO}$ and $\mathrm{BrO}$ during the 2007 and 2008 GSHOX experiments at Summit. In this study we provide a proof of principle that photochemistry in the snow is a source of gas phase nitrogen oxides and reactive bromine in the boundary layer at Summit and other snow covered areas. We investigate whether local production of gas phase reactive nitrogen and bromine species in the surface snowpack can explain atmospheric measurements of $\mathrm{BrO}, \mathrm{NO}$, and $\mathrm{O}_{3}$ made at Summit, Greenland during 3 days in June 2008. We focus on 2008 instead of 2007 because the boundary layer profiles of temperature and humidity were measured as part of the suite of measurements in 2008. The comparison also serves as a validation of the model framework. We also consider the current modeling results in the context of previous field experiments at Summit. In a companion paper, we will discuss the impact of halogen chemistry on $\mathrm{HO}_{\mathrm{x}}$ and model sensitivity to a number of input parameters and environmental conditions including $\mathrm{HONO}, \mathrm{H}_{2} \mathrm{O}_{2}$ and $\mathrm{HO}_{\mathrm{x}}$ chemistry (Thomas et al., 2011).

\section{Model description}

In this section we present an overview of the new coupled atmosphere-snow model, MISTRA-SNOW, with a focus on the new snow module, and the initialization chosen for Summit, Greenland for June 2008. Figure 1 provides an overview of the physical and chemical processes included in the coupled model. The boundary layer model MISTRA was originally a microphysical model and was later expanded to include gas, aerosol, and cloud droplet chemistry (von Glasow et al., 2002a,b). MISTRA also includes a description of the dynamics and thermodynamics and treats feedbacks between radiation and particles.

\subsection{1-D vertical grid}

The physical properties of the snowpack change rapidly with depth. The rate at which photochemical reactions proceed decreases rapidly with depth near the snow surface because the actinic flux decays exponentially with depth. To account for the fine spatial scale over which snowpack chemistry and physics changes, the snow/firn is represented as a onedimensional vertical $\log$ scale grid to a depth of $3 \mathrm{~m}$ with a total of 20 grid cells. The atmosphere is represented by an evenly spaced grid with $1 \mathrm{~m}$ vertical grid spacing in the lowest $100 \mathrm{~m}$ and a logarithmically spaced grid from 100 $2000 \mathrm{~m}$. The fine grid spacing in the atmosphere is necessary to correctly simulate the shallow boundary layers that occur during evening hours over snow covered regions. The snowpack and atmosphere are coupled at the surface of the snowpack through gas flux that occurs by both diffusion and wind pumping (discussed below).

\subsection{Physical properties of snow}

The physical description of the snowpack in the model includes the liquid like layer (LLL) thickness, snow grain radius, density, liquid water content, and heat capacity. For calculation of mass transfer between the gas phase and the ice we assumed spherical snow grains. We used a snow grain radius of $1 \mathrm{~mm}$ that was chosen based on prior campaign data (unpublished data from the campaign summarized by Dibb et al., 2007). The density $\left(\rho=0.3 \mathrm{~g} \mathrm{~cm}^{-3}\right)$, was chosen based on typical conditions observed at Summit (Z. Courville, personal communication, 2008). We treat the LLL as a $10 \mathrm{~nm}$ thick LLL on the surface of a spherical snow grain (Rosenberg, 2005). We took the LLL thickness from the compilation of Rosenberg (2005) that includes data for the thickness of the liquid layer on the surface of pure ice. There is a wide range of measurements in the temperature range relevant to our model. Given that measurements for pure ice range from $1 \mathrm{~nm}$ to $\sim 30 \mathrm{~nm}$, we picked a thickness in the mid range of these measurements. There is also evidence that the liquid layer thickness varies with temperature and ion content. However, there is no clear parameterization of how thickness varies and we have not included temperature or ion content dependence in the current model version. Liquid water content was calculated based on density, snow grain radius, and liquid layer thickness.

\subsubsection{Heat flux through the snowpack}

The heat flux in the snowpack is explicitly calculated and the temperatures are used for snow chemistry and calculation of gas phase diffusion constants. The effective thermal conductivity of snow $k_{\text {eff }}$ is the proportionality factor between the temperature gradient $d T / d z$ and the heat flux $q$ :

$q=-k_{\mathrm{eff}} \frac{d T}{d z}$

$k_{\text {eff }}$ has contributions from several physical processes including heat flux through the solid ice and interstitial air and has a wide range of measured values. For dry snow, values for $k_{\text {eff }}$ range between $0.025-0.65 \mathrm{~W} \mathrm{~m}^{-1} \mathrm{~K}^{-1}$ and $k_{\text {eff }}$ values of windpacked surface snow on polar ice sheets vary from $0.15-0.20 \mathrm{~W} \mathrm{~m}^{-1} \mathrm{~K}^{-1}$ for a density near $0.35 \mathrm{~g} \mathrm{~cm}^{-3}$ (Domine et al., 2008). Given these data, we used $k_{\text {eff }}=$ $0.25 \mathrm{~W} \mathrm{~m}^{-1} \mathrm{~K}^{-1}$ in the model run presented here. In order to calculate the temperature variation in the snowpack we use the time dependent equation:

$\frac{\partial T}{\partial t}=\frac{\partial}{\partial z}\left(\frac{k_{\mathrm{eff}}}{\rho C_{p}} \frac{\partial T}{\partial z}\right)$

where $\rho$ is the density of the snowpack and $C_{p}$ is the heat capacity.

To calculate the temperature of the surface and force a diurnal cycle in the atmospheric boundary layer, the upper 
Table 1. Parameters to calculate the vertical wind pumping speed and diffusion a Summit, Greenland.

\begin{tabular}{llrll}
\hline Parameter & Description & Value & Units & Reference \\
\hline$\mu$ & dynamic viscosity of air & $1.6 \times 10^{-5}$ & Pa s & List (1884) \\
$\lambda_{\text {surf }}$ & relief wavelength & $3.0 \times 10^{-2}$ & $\mathrm{~m}$ & see text \\
$h$ & relief amplitude & $1.5 \times 10^{-2}$ & $\mathrm{~m}$ & see text \\
$\alpha$ & horizontal aspect ratio of relief & 1 & unitless & Albert and Hawley (2002) \\
$k$ & permeability & $8.0 \times 10^{-10}$ & $\mathrm{~m}^{2}$ & Albert and Shultz (2002) \\
$u_{10}$ & horizontal wind speed & 3.0 & $\mathrm{~m} \mathrm{~s}^{-1}$ & average of NOAA observations \\
$\tau$ & tortuosity & 0.5 & unitless & Albert and Shultz (2002) \\
\hline
\end{tabular}

* Mefford (2010)

boundary condition for integration of Eq. (2), is calculated according to:

$T_{\text {surf }}=T_{\text {amp }}\left(1+\sin \left[2 \pi\left(\frac{t_{\mathrm{h}}}{24}-\frac{t_{\min }+6}{24}\right)\right]\right) / 2$

where $T_{\text {surf }}$ is the surface temperature, $T_{\mathrm{amp}}$ is the amplitude of the surface temperature oscillation in $\mathrm{K}, t_{\mathrm{h}}$ is the hour in local time, and $t_{\min }$ is the hour when the surface temperature reaches a minimum. We use a diurnal variation in the snow surface temperature guided by snow surface temperature measurements (B. Seok and D. Helmig, personal communication, 2008) to drive the temperature variability in the snowpack. Similarly, we use this temperature as the lower boundary for the atmosphere ensuring consistency between the snow surface and the atmosphere. The values used for $t_{\min }$ and $T_{\mathrm{amp}}$ in the model run are $t_{\min }=2$ (the temperature reaches a minimum at $2 \mathrm{am}$ local time) and $T_{\mathrm{amp}}=20(\mathrm{a} 20 \mathrm{~K}$ diurnal variation in the surface temperature). In future versions of the model we plan to solve for the surface energy budget in order to more completely treat snow-atmosphere heat flux.

\subsubsection{Gas transport in the firn}

Gas transport in the snow and firn is treated as the sum of two process, wind pumping and molecular diffusion. The diffusion constant for gases, $D_{\mathrm{g}}$, is approximated as $D_{\mathrm{g}}=\lambda_{\text {air }} \bar{v} / 3$ (Gombosi, 1994) using the mean molecular speed $(\bar{v}=\sqrt{8 R T /(M \pi)}$ where $M$ is the molar mass) and the mean free path length $\left(\lambda_{\text {air }}\right)$. The vertical wind pumping is calculated according to Cunningham and Waddington (1993):

$U_{\text {firn }}=\frac{6 k \rho_{\text {air }}}{\pi \mu \lambda_{\text {surf }}} \frac{h}{\lambda_{\text {surf }}} \frac{\sqrt{\alpha^{2}+1}}{\alpha} u_{10}^{2} \exp \left(-\frac{z}{\delta}\right)$

using $\delta$ defined as

$\delta=\frac{1}{2} \frac{\alpha}{\sqrt{\alpha^{2}+1}} \frac{\lambda_{\text {surf }}}{\pi}$

where $U_{\text {firn }}$ is the vertical wind pumping speed, $k$ is the permeability, $\rho_{\text {air }}$ is the density of air, $\mu$ is the dynamic viscosity of air, $\lambda_{\text {surf }}$ is the relief wavelength, $h$ is the relief amplitude, $\alpha$ is a horizontal aspect ratio of the relief relative to wind direction, $z$ is the depth from the snow surface, and $u_{10}$ is the horizontal wind speed $10 \mathrm{~m}$ above the snow surface. The parameters used for modeling wind pumping are summarized in Table 1. The horizontal and vertical relief size is chosen based on our visual observations in the field during the GSHOX campaign.

The total gas transport is the sum of both molecular diffusion and wind pumping. We calculate the effective diffusion constant $\kappa$ (in $\mathrm{m}^{2} \mathrm{~s}^{-1}$ ) as the sum of both contributing terms

$\kappa=\tau D_{\mathrm{g}}+U_{\text {firn }} \Delta z$

where $D_{\mathrm{g}}$ is the gas phase diffusion constant (both $D_{\mathrm{g}}$ and $U_{\text {firn }}$ are a fuction of depth), $\tau$ is the tortuosity, and $\Delta z$ is the grid spacing. Note that the second term of this equation represents an area-averaged effective vertical diffusivity arising from the wind pumping.

Due to the uncertainty in the representation of wind pumping we have completed a number of sensitivity runs to understand how the system behaves. Plots of the 2 and $10 \mathrm{~m}$ wind speed during the three day model focus period can be found in the Supplement. We have also included runs using the using the hourly binned measured wind speed instead of a constant $3 \mathrm{~m} \mathrm{~s}^{-1}$ wind speed that show the model results are very similar to the base run presented here.

\subsection{Chemistry}

The model treats gas and aqueous chemistry in the atmosphere and snowpack as well as transfer between the gas and aqueous phases, heterogenous reactions on aerosols are included in the atmosphere. A complete list of reactions for the new model including both the gas and aqueous phases as well as the Henry's law constants and mass accommodation coefficients are included in the Supplement. The reaction set is based on von Glasow and Crutzen (2004) with updated rate constants according to Sander et al. (2006) and Atkinson et al. (2006). The aqueous reaction mechanism was originally developed for chemistry in aerosol particles and has been modified to be consistent with the mechanisms for 


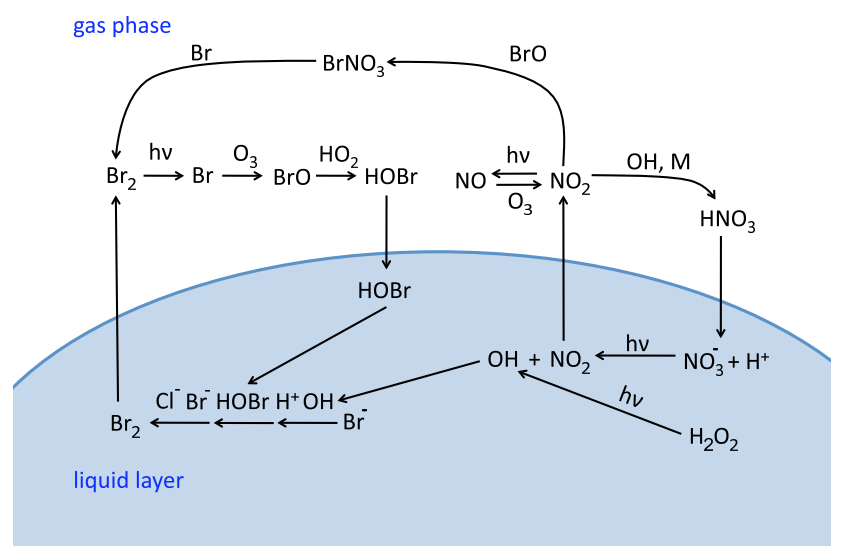

Fig. 2. Chemical pathways important for $\mathrm{NO}_{\mathrm{x}}$ and reactive bromine cycling at Summit, Greenland.

$\mathrm{NO}_{\mathrm{x}}$ release from snow recommended by Jacobi and Hilker (2007) as well as Boxe and Saiz-Lopez (2008). A reaction scheme including the most important chemical reactions discussed here is summarized in Fig. 2.

The prognostic equation for the concentration of a gas phase chemical species $c_{\mathrm{g}}$ (in $\mathrm{mol} \mathrm{m}_{\text {air }}^{-3}$ ) including wind pumping, diffusion, chemical production and destruction, and exchange with the aqueous phases is given by

$$
\frac{\partial c_{\mathrm{g}}}{\partial t}=\frac{\partial}{\partial z}\left(\kappa \rho(z) \frac{\partial c_{\mathrm{g}} / \rho(z)}{\partial z}\right)-D+P-k_{t}\left(w_{1} c_{\mathrm{g}}-\frac{c_{a}}{k_{H}^{c c}}\right)(7)
$$

where $\kappa$ denotes the sum of diffusion and wind pumping (described above). $P$ and $D$ are chemical production and loss terms, $k_{H}^{c c}$ is the dimensionless Henry constant obtained by $k_{H}^{c c}=k_{H} R T$, where $k_{H}$ is in mol m${ }^{-3} \mathrm{~Pa}^{-1}, w_{1}$ is the dimensionless liquid water content $\left(\mathrm{m}_{\mathrm{aq}}^{3} / \mathrm{m}_{\text {air }}^{3}\right)$ of the snow LLL. The last term in Eq. (7) describes the transport from the gas phase into the aqueous phase according to the formulation by Schwartz (1986) (see also Sander, 1999a). For a single snow grain, the mass transfer coefficient $k_{t}$ is defined as

$k_{t}=\left(\frac{r^{2}}{3 D_{\mathrm{g}}}+\frac{4 r}{3 \bar{v} \alpha}\right)^{-1}$

with the snow grain radius $r$, the mean molecular speed $\bar{v}$ (defined above in Sect. 2.2.2), the accommodation coefficient $\alpha$ (see Supplement), and the gas phase diffusion coefficient $D_{\mathrm{g}}$ (defined above).

\subsubsection{Calculation of photolysis rates}

Photolysis rates in the atmosphere are calculated online as a function of altitude using the method of Landgraf and Crutzen (1998) with a four stream radiation code. Photolysis rates in the snowpack are calculated according to:

$$
E_{\lambda}(z)=E_{\lambda}(z=0) \exp \left(-z / \epsilon_{\lambda}\right)
$$

where $E_{\lambda}(z)$ is the actinic flux at depth $z, E_{\lambda}(z=0)$ is the incident irradiance at the surface of the snowpack $(z=0$ at the surface of the snowpack), and $\epsilon_{\lambda}$ is defined as the e-folding depth (King and Simpson, 2001). We use an e-folding depth of $\epsilon_{\lambda}=10 \mathrm{~cm}$, measured for nitrate at Summit, Greenland (Galbavy et al., 2007) for all species that undergo photolysis. Surface and in snow photolysis rates for $\mathrm{NO}_{2}$ are shown in Fig. 3. The modeled surface photolysis rates $\left(\mathrm{N}_{\mathrm{NO}_{2}}\right)$ are in good agreement with measured rates on 10 June 2008 . The measurements of $J_{\mathrm{NO}_{2}}$ show similar agreement with model results (not shown) for the remaining two days relevant for this model run.

\subsection{Model initialization}

The model is initialized with gas and aqueous phase concentrations. The initial surface gas phase and the LLL concentrations are summarized in Table 2 . The initial gas phase mixing ratios in the interstitial air are vertically uniform for species with long atmospheric lifetimes (for example $\mathrm{CO}$ ) and decay with snow depth for reactive species (for example $\mathrm{O}_{3}$ ). Aqueous phase concentrations are initially equal to the Henry's law equilibrium concentration for volatile species. For nonvolatile species (ions) the initial concentration is equal to:

$C_{\text {liquid layer }}=\phi \times C_{\text {snow }}$

where $C_{\text {snow }}$ is the concentration in melted surface snow measured by liquid chromatography at Summit during the days chosen from the GSHOX field campaign period for the model runs. Ion partitioning between the core and surface layer is represented by $\phi$, an enhancement factor that accounts for the difference between the measured (bulk) concentration in melted snow and the concentration in the LLL. The fraction of the ions present in the LLL is given by $\phi / \phi_{\max }$, where $\phi_{\max }$ is determined by the properties of the snow grain and the LLL. The exact value of $\phi_{\max }$ is determined by the ratio of LLL volume to the snow grain volume (for the parameters used to describe snow grains in our model $\phi_{\max }=3.3 \times 10^{4}$ ). The parameter $\phi$ describes how ions are distributed between the LLL and the ice-like core of the snow grain and is a fitted parameter in our model. Although $\phi$ is not well known, exclusion of non-volatile species from the ice matrix and formation of a liquid brine during freezing is a well known phenomenon. In addition, gas deposition followed by dissociation in the LLL (for example for $\mathrm{HNO}_{3}$ deposition followed by dissociation to form $\mathrm{H}^{+}$and $\mathrm{NO}_{3}^{-}$) should also increase surface ion concentrations compared to the bulk composition. The extent to which ions are mobile in the ice matrix, and how temperature cycling affects ion segregation at the surface of snow grains also affects ion partitioning.

Experiments suggest that chloride is concentrated in quasibrine layers present in frozen sodium chloride solutions (Cho et al., 2002) and that the presence of chloride ions impacts water structure at the ice-air interface (Kahan et al., 2007). 
Table 2. Initial gas and liquid-like layer (LLL) concentrations for model runs conducted based measurements taken in June 2008 as well as previous measurements at Summit, Greenland.

\begin{tabular}{|c|c|c|c|c|c|c|}
\hline $\begin{array}{l}\text { Species } \\
\text { unit }\end{array}$ & $\begin{array}{l}\text { gas phase (surface) } \\
\text { ppb }\end{array}$ & Reference & $\begin{array}{c}\text { LLL (initial) } \\
\mathrm{M}\end{array}$ & $\begin{array}{c}\text { measured (melted surface snow) } \\
\text { M }\end{array}$ & $\phi$ & Reference \\
\hline $\mathrm{O}_{3}$ & 55 & measured & - & - & - & - \\
\hline $\mathrm{NO}_{2}$ & 0.02 & $\begin{array}{l}\text { Jacobi et al. (2004) and } \\
\text { Hutterli et al. (2001) }\end{array}$ & - & - & - & - \\
\hline $\mathrm{HNO}_{3}$ & 0.01 & Dibb et al. (2002) & - & - & - & - \\
\hline $\mathrm{HCHO}$ & 0.1 & Jacobi et al. (2004) & $2.0 \times 10^{-5}$ & - & 1 & $\begin{array}{l}\text { Henry's law based on } \\
\text { Chameides (1984) }\end{array}$ \\
\hline $\mathrm{H}_{2} \mathrm{O}_{2}$ & 0.4 & $\begin{array}{l}\text { Jacobi et al. (2004) and } \\
\text { Hutterli et al. (2001) }\end{array}$ & $1.0 \times 10^{-3}$ & - & 1 & $\begin{array}{l}\text { Henry's law based on } \\
\text { Lind and Kok (1994) }\end{array}$ \\
\hline $\mathrm{CO}_{2}$ & 388 (ppm) & NOAA (Flask) ${ }^{1}$ & - & - & - & - \\
\hline $\mathrm{CO}$ & 130 & measured & - & - & - & - \\
\hline $\mathrm{Br}^{-}$ & - & - & $3.3 \times 10^{-4}$ & $1.0 \times 10^{-8}$ & $3.3 \times 10^{4}$ & Dibb et al. (2010) \\
\hline $\mathrm{Cl}^{-}$ & - & - & $1.8 \times 10^{-2}$ & $5.5 \times 10^{-7}$ & $3.3 \times 10^{4}$ & Dibb et al. (2010) \\
\hline $\mathrm{NO}_{3}^{-}$ & - & - & $8.8 \times 10^{-3}$ & $3.5 \times 10^{-6}$ & $2.5 \times 10^{3}$ & Dibb et al. (2010) \\
\hline $\mathrm{H}^{+}{ }^{3}$ & - & - & $8.8 \times 10^{-3}$ & $3.5 \times 10^{-6}$ & $2.5 \times 10^{3}$ & equal to nitrate ${ }^{2}$ \\
\hline $\mathrm{Na}^{+}$ & - & - & $1.9 \times 10^{-2}$ & $5.6 \times 10^{-7}$ & $3.3 \times 10^{4}$ & counter ion ${ }^{3}$ \\
\hline
\end{tabular}

${ }^{1}$ Conway et al. (2009).

${ }^{2}$ Assumed nitrate is primarily from from $\mathrm{HNO}_{3}$ deposition (therefore $\left[\mathrm{H}^{+}\right]_{t=0}$ is equal to $\left[\mathrm{NO}_{3}^{-}\right]_{t=0}$ ).

${ }^{3}$ Counter ion for halides.

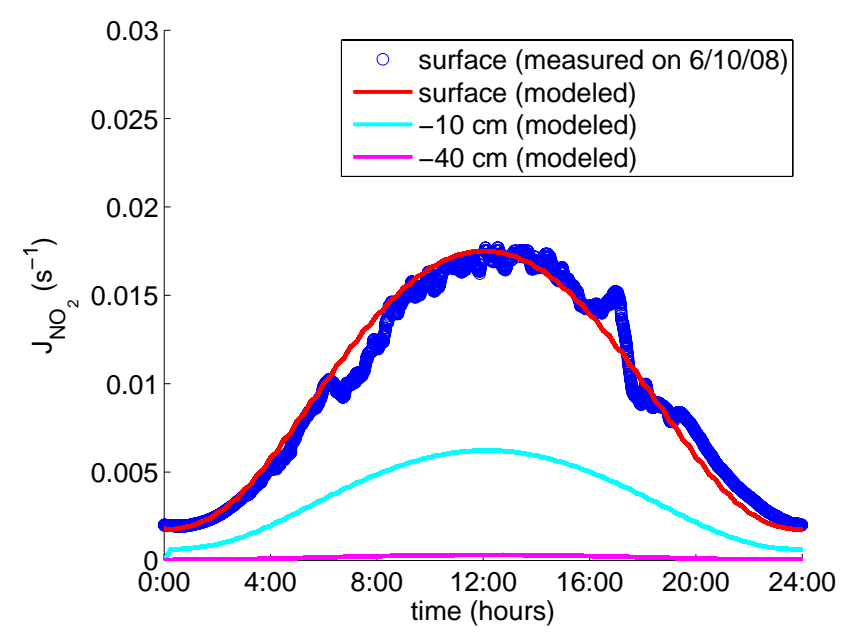

Fig. 3. $J_{\mathrm{NO}_{2}}$ measured on 10 June 2008 (in blue) compared with the modeled $J_{\mathrm{NO}_{2}}$ (in red) at the snow surface. Modeled $J_{\mathrm{NO}_{2}}$ data at depths of $10 \mathrm{~cm}$ and $40 \mathrm{~cm}$ are also shown.

Molecular dynamics simulations provide evidence that chloride is excluded from the ice matrix upon freezing (Vrbka and Jungwirth, 2005) and that chloride and bromide are more concentrated at the surface of liquid water solutions at ambient temperatures than nitrate (Jungwirth and Tobias, 2001, 2002; Mucha et al., 2005; Thomas et al., 2007). There is also evidence that the quasi-brine layer present in frozen $\mathrm{NaCl}$ solutions is a function of both the ion concentration and temperature (Cho et al., 2002) and that the composition is well described by freezing point depression. Pure ice also has a significant liquid-like layer at the surface that forms due to anisotropy at the ice-air interface in the absence of ions, as summarized by Rosenberg (2005). The difference between the quasi-brine layer and liquid layer at the surface of ice has recently been discussed in more detail by Kuo et al. (2011). Given the presence of a liquid layer on pure ice and the knowledge that chloride is concentrated in a liquid layer upon freezing, we chose $\phi_{\mathrm{Cl}, \mathrm{Br}}$ such that all bromide and chloride ions observed in melted surface snow are present in the LLL. Our initial chloride and bromide concentration (as well as the sum of all ions in the liquid layer) is far below the liquid layer concentration suggested by freezing point depression ( $>5 \mathrm{M}$ ). However, because the properties of the ice-air interface contain a combination of the properties of the quasi-brine layer present internally in the ice matrix and the properties of the pure ice-air interface we believe this is a reasonable assumption for the composition of the liquid layer.

For nitrate, the evidence for how to distribute ions between the ice core and the LLL is less clear. One could assume that nitrate behaves the same as chloride and bromide resulting in all of the ions in the LLL. But this is not necessarily the correct conclusion as nitrate and the halides are predicted to behave differently at the air-water interface. In addition, molecular dynamics simulations show bromide has an influence on the amount of nitrate present at the surface of thin water films, but that the effect is dependent on the counter ion present in the solution (Richards et al., 2011). Recent work by Křepelová et al. (2010) that included a surface specific probe of the ice-air interface did not show evidence for a 
nanometer thick liquid-like layer upon exposure to gas phase $\mathrm{HNO}_{3}$, although experiments were conducted at a lower temperature $(230 \mathrm{~K})$. One could also calculate the initial nitrate concentration from the Henry's law equilibrium concentration of $\mathrm{HNO}_{3}$ at a given temperature, which would result in much lower initial LLL nitrate. There are many reasonable initializations for nitrate that range from $100 \%$ to $<1 \%$ of the nitrate in the liquid layer. Given this we adjusted the initial $\mathrm{LLL} \mathrm{NO}_{3}^{-}$so that the peak modeled atmospheric NO mixing ratio matched the measured value, such that $6 \%$ of the total available nitrate in melted snow is in the LLL. In future work we plan to test different models of the LLL thickness, structure, and composition test model sensitivity to different representations of the LLL. We have completed an initial set of runs to demonstrate the sensitivity to different nitrate LLL initializations (presented in the Supplement). A more complete set of sensitivity runs looking at model behavior for different LLL compositions will be discussed in an accompanying manuscript (Thomas et al., 2011).

Aqueous phase chemistry to oxidize bromide to bromine is known to be $\mathrm{pH}$ dependent, therefore particular care needs to be taken in initializing the $\mathrm{pH}$ in the LLL. Assuming that $\mathrm{HNO}_{3}$ uptake is the major source of LLL acidity (noting that $\mathrm{HCl}$ makes a less significant contribution), we assume one $\mathrm{NO}_{3}^{-}$ion has one corresponding $\mathrm{H}^{+}$ion. We therefore use the initial nitrate concentration in order to determine the initial $\mathrm{H}^{+}$concentration in the LLL, for the conditions described here the initial $\mathrm{pH}=2$. It should also be noted that the current model set-up and initilization is not intended for seasonal simulations for which large scale forcings such as long range transport and deposition of bromine and nitrate to the snow and snow physics would have to be considered.

The atmospheric aerosol number and size distribution was initialized by parameterizing aerosol size distribution measurements at Summit on 12 June 2008. The size distribution consists of fine aerosol particles primarily smaller than $0.1 \mu \mathrm{m}$ with an average total aerosol number concentration of $168 \mathrm{~cm}^{-3}$. Particles are initialized with $\mathrm{Cl}^{-}, \mathrm{Br}^{-}, \mathrm{NO}_{3}^{-}, \mathrm{H}^{+}$, and $\mathrm{Na}^{+}$based on collected filter samples during the same time period (Dibb et al., 2010), while also ensuring initial ion balance in the aerosol.

\section{Results and discussion}

We focused on three days of observations (10 June13 June 2008) made during the GSHOX experiment at Summit, Greenland in order to test MISTRA-SNOW. This focus period was chosen due to consistent meteorological conditions during the three day focus period as well as simultaneous measurements of $\mathrm{O}_{3}, \mathrm{NO}, \mathrm{BrO}, \mathrm{HO}_{\mathrm{x}}$. In addition, FLEXPART emission sensitivity maps indicate that the air at Summit during this period had been cycling over the Greenland snowpack for at least three days prior to the focus period without influence of marine air (Stutz et al., 2011). There- fore, we anticipate that the composition of local air masses at Summit was strongly influenced by contact with the surface snowpack.

\subsection{Boundary layer evolution and mixing}

Atmospheric trace gas concentrations at Summit during this period, and above many other snow covered surfaces, are strongly modulated by diurnal boundary layer evolution. Radiative cooling at night causes the formation of shallow and stable temperature inversions, which often extend from the ground to $20-30 \mathrm{~m}$ in height. In the morning, solar surface heating leads to the breakup of this layer, forming a well mixed daytime boundary layer, typically $200-300 \mathrm{~m}$ high during the campaign. The three days chosen to test our model generally follow the described boundary layer behavior (Fig. 4). The evolution of temperature throughout the three day model run is shown in Fig. 4a (atmosphere) and b (snow). Measured boundary layer profiles are shown in Fig. $4 \mathrm{c}$ and modeled boundary layer profiles at the corresponding times are shown in panel d. Both the model and measurements show that a shallow inversion layer forms during the night time hours when the sun nears the horizon. At mid-day surface warming leads to rapid growth of the boundary layer. The comparison of measured and modeled temperature profiles at Summit during the 2008 campaign shows that the model accurately captures mixing between the boundary layer and the overlying air. The temperature evolution in the snowpack (Fig. 4b) is also consistent with measured in snow temperature profiles at Summit during late June 2008 (B. Seok and D. Helmig, personal communication, 2008).

\section{2 $\quad \mathrm{NO}_{\mathrm{x}}$ mixing ratios}

A number of studies have reported high levels of atmospheric $\mathrm{NO}_{\mathrm{x}}$ above the snow in Greenland as well as at South Pole Station in Antarctica and elsewhere (e.g. Honrath et al., 1999, 2000, 2002; Jones et al., 2000; Davis et al., 2001; Dibb et al., 2002). At Summit, the coupled MISTRA-SNOW model predicts $\mathrm{NO}$ and $\mathrm{NO}_{2}$ mixing ratios in the atmosphere result from nitrate photochemistry occurring in the LLL (Figs. 5 and 6). In the model, nitrate in snow grains is photolyzed to form $\mathrm{NO}_{2}$ (Reaction R1), which is subsequently transferred from the LLL to the gas phase (Reaction R2).

$\mathrm{NO}_{3}^{-}(\mathrm{aq})+\mathrm{h} v \stackrel{\mathrm{H}^{+}}{\longrightarrow} \mathrm{NO}_{2}(\mathrm{aq})+\mathrm{OH}(\mathrm{aq})$

$\mathrm{NO}_{2}(\mathrm{aq}) \longrightarrow \mathrm{NO}_{2}(\mathrm{~g})$

A second, minor, nitrate photolysis channel is also present that produces $\mathrm{NO}_{2}^{-}$and $\mathrm{O}^{3} \mathrm{P}$ (Reaction $\mathrm{R} 3$ ).

$\mathrm{NO}_{3}^{-}(\mathrm{aq})+\mathrm{h} v \longrightarrow \mathrm{NO}_{2}^{-}(\mathrm{aq})+\mathrm{O}^{3} \mathrm{P}(\mathrm{aq})$ 

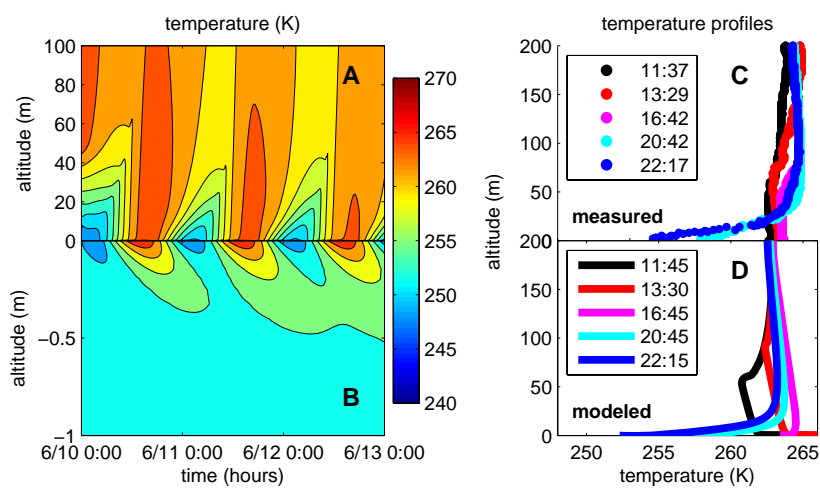

Fig. 4. Modeled temperature evolution of the atmosphere and firn in the upper panels (A) and (B). Tethersonde measurements $(\mathbf{C})$ compared with modeled temperature profiles $(\mathbf{D})$.

$\mathrm{NO}_{2}$ in the interstitial air is in a pseudo steady state (PSS) with NO (Reactions R4 and R5).

$\mathrm{NO}_{2}(\mathrm{~g})+\mathrm{h} v \stackrel{\mathrm{O}_{2}}{\longrightarrow} \mathrm{NO}(\mathrm{g})+\mathrm{O}_{3}(\mathrm{~g})$

$\mathrm{NO}(\mathrm{g})+\mathrm{O}_{3}(\mathrm{~g}) \longrightarrow \mathrm{NO}_{2}(\mathrm{~g})+\mathrm{O}_{2}(\mathrm{~g})$

Under the conditions present at Summit NO reacts more quickly with $\mathrm{O}_{3}$ than with $\mathrm{HO}_{2}$ and Reaction (R5) is the dominant $\mathrm{NO}_{2}$ production mechanism in the gas phase. The $\mathrm{NO}_{\mathrm{x}}$ mixture produced in the snow is then mixed upwards and downwards via a combination of wind pumping and diffusion. As air is mixed downward, out of the region where photochemistry occurs, the PSS shifts to $\mathrm{NO}_{2}$ due to the lower actinic fluxes deeper in the snow. As air is mixed upwards out of the snowpack and actinic flux increases the PSS shifts towards NO, until it reaches the atmospheric PSS at the surface. The surface $\mathrm{NO}_{\mathrm{x}}$ mixing ratios are also modulated by boundary layer height (discussed below).

In order to model the absolute levels of NO in the atmosphere, the nitrate partitioning between ice and the LLL was adjusted so that $6 \%$ of the total nitrate in melted surface snow was present in the LLL. The initial nitrate concentration is an adjustable parameter that was used to model NO photochemistry. While there is no direct measurement that indicates how much nitrate should be in the liquid layer vs. the core of the snow grain, the resulting predicted NO mixing ratios are in excellent agreement with atmospheric measurements of NO during the selected 3 day period at Summit in 2008 (Fig. 5c).
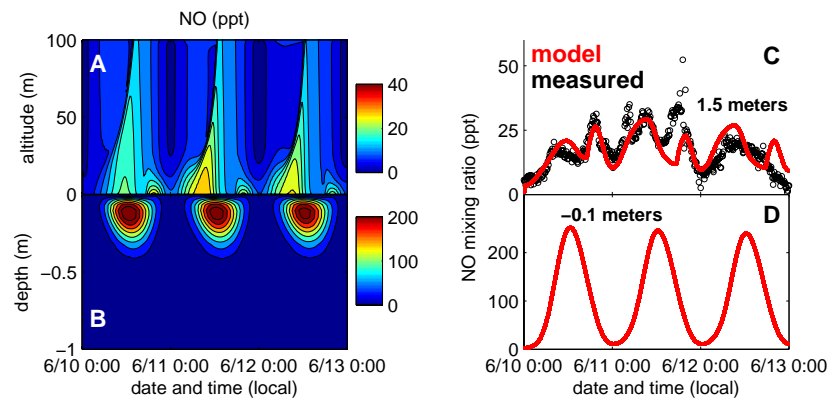

Fig. 5. Modeled NO mixing ratios in the atmosphere (A) and interstitial (B) air. Modeled mixing ratios in the atmosphere at an altitude of $1.5 \mathrm{~m}$ above the snowpack are compared with measurements in (C). Predicted interstitial air mixing ratios $10 \mathrm{~cm}$ below the snow surface are shown in (D).

Plots of measured and modeled NO atmospheric mixing ratios (Fig. 5a and c) clearly show the vertical distribution of $\mathrm{NO}$ is impacted by the boundary layer evolution. Gas phase $\mathrm{NO}_{\mathrm{x}}$ emissions from nitrate in the snow grains to the interstitial air peak with solar radiation, however the diurnal profile of atmospheric NO mixing ratios do not peak at solar noon. Fluxes out of the snowpack are modulated by the influence of mixing processes in the atmosphere. In the early morning NO is mixed upwards and confined to a shallow layer near the surface. The boundary layer breaks up later during the day and NO is rapidly mixed into a larger volume, then in the late afternoon NO is again confined to a shallow layer. The dip in mid-day NO mixing ratios is not due to a decrease in $\mathrm{NO}_{\mathrm{x}}$ in the interstitial air.

A snow source of $\mathrm{NO}_{\mathrm{x}}$ combined with atmospheric mixing explains the behavior of $\mathrm{NO}$ at $1.5 \mathrm{~m}$ altitude, resulting in NO peaks in the early morning and the later afternoon. It is important to note that NO does not disappear completely at night, as the $\mathrm{NO}_{2}$ photolysis rate does not drop to zero during this time of the year at Summit. Agreement between model predicted NO mixing ratios and measurements provides strong evidence that the MISTRA-SNOW model contains a reasonable representation of snowpack $\mathrm{NO}_{\mathrm{x}}$ chemistry and mixing processes. It should be noted here that the diurnal variation of $\mathrm{NO}$ mixing ratios are obtained without adjustment of the model parameters, while the absolute values were obtained by adjusting the nitrate partitioning between ice and the LLL.

Unlike $\mathrm{NO}, \mathrm{NO}_{2}$ was not measured during the GSHOX campaign. Therefore, there are no $\mathrm{NO}_{2}$ measurements to directly compare to model calculations during this period. Figure $6 \mathrm{a}$ and $\mathrm{c}$ show that the model predicts $\mathrm{NO}_{2}$ peaks in the atmosphere during the night. The model predicts $\mathrm{NO}_{2}$ mixing ratios up to a maximum of $60 \mathrm{ppt}$ at night, which are confined to the lowest $20 \mathrm{~m}$ of the atmosphere. The majority of night time $\mathrm{NO}_{2}$ in the atmosphere results from upward mixing of $\mathrm{NO}_{2}$ in interstitial air, where a large excess of $\mathrm{NO}_{2}$ 

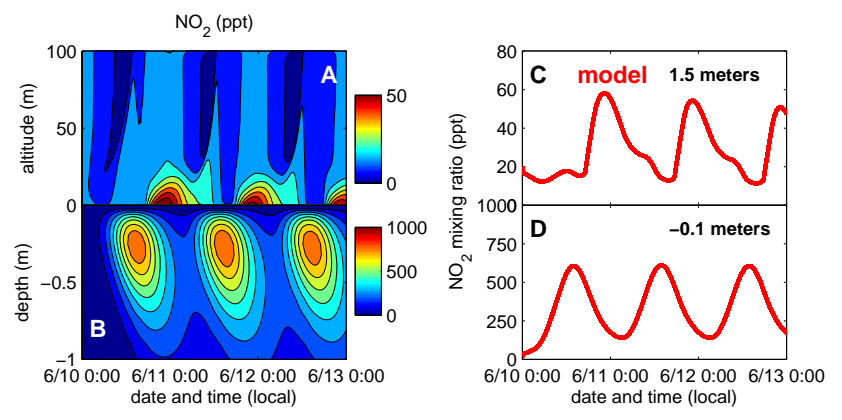

Fig. 6. Modeled $\mathrm{NO}_{2}$ mixing ratios in the atmosphere (A) and interstitial (B) air. Modeled mixing ratios in the atmosphere at an altitude of $1.5 \mathrm{~m}$ above the snowpack are shown in panel $(\mathbf{C}), \mathrm{NO}_{2}$ was not measured during the field campaign. Predicted interstitial air mixing ratios $10 \mathrm{~cm}$ below the snow surface are shown in (D).

persists into the night. A small fraction of the night-time $\mathrm{NO}_{2}$ is also produced from the conversion of $\mathrm{NO}$ to $\mathrm{NO}_{2}$. While this behavior does not reproduce the $\mathrm{NO}_{\mathrm{x}}$ diurnal profiles measured at Summit in summer 1999, it is more consistent with measurements taken during summer of 2000 when the peak occurred later in the evening (Honrath et al., 2002). In order to definitively determine if the predicted $\mathrm{NO}_{2}$ mixing ratios in both the atmosphere and interstitial air are reasonable direct comparison with simultaneous measurements of both $\mathrm{NO}$ and $\mathrm{NO}_{2}$ would be requried. However, the excellent agreement with measured NO mixing ratios suggests that the model contains a reasonable representation of $\mathrm{NO}_{\mathrm{x}}$ chemistry.

Interstitial air $\mathrm{NO}$ and $\mathrm{NO}_{2}$ mixing ratios have a clear diurnal profile modulated by available sunlight. NO mixing ratios have a maximum at $10 \mathrm{~cm}$ depth $(230 \mathrm{ppt})$ as shown in Fig. $5 \mathrm{~b}$ and $\mathrm{d}$. The loss by vertical mixing and transport is efficient near the surface, thus rapidly transporting NO to the atmosphere above from a depth of $10 \mathrm{~cm}$. The shift in the $\mathrm{NO}_{\mathrm{x}}$ PSS, on the other hand, leads to a decrease in NO with depth. Peak $\mathrm{NO}_{2}$ mixing ratios of up to $700 \mathrm{ppt}$ occur deeper in the snowpack (approx. $20 \mathrm{~cm}$ depth, Fig. $6 \mathrm{~b}$ and d) due to the longer lifetime of $\mathrm{NO}_{2}$ as well as the shift in $\mathrm{NO}_{\mathrm{x}}$ PSS towards $\mathrm{NO}_{2}$ with depth.

There is some storage of reactive nitrogen as $\mathrm{N}_{2} \mathrm{O}_{5}$ (formed via Reaction R6) and $\mathrm{BrNO}_{3}$ (formed via Reaction R7) in the snowpack during the evening hours. $\mathrm{N}_{2} \mathrm{O}_{5}$ mixing ratios increase with depth due to a decrease in actinic flux. Up to $40 \%$ gas phase nitrogen is present as $\mathrm{N}_{2} \mathrm{O}_{5}$ deep in the firn. $\mathrm{BrNO}_{3}$ is only a small reservoir for gas phase nitrogen, but is significant as a reactive bromine reservoir (discussed below). A more detailed discussion of these species and model sensitivity to surface reactions involving $\mathrm{BrNO}_{3}$ and $\mathrm{N}_{2} \mathrm{O}_{5}$ as well as their role in snowpack chemistry will be provided in a companion paper (Thomas et al., 2011).
$\mathrm{NO}_{2}+\mathrm{NO}_{3} \stackrel{\mathrm{M}}{\longrightarrow} \mathrm{N}_{2} \mathrm{O}_{5}$

$\mathrm{BrO}+\mathrm{NO}_{2} \stackrel{\mathrm{M}}{\longrightarrow} \mathrm{BrNO}_{3}$

Cycling of reactive nitrogen species involves both emission of $\mathrm{NO}_{\mathrm{x}}$ as well as deposition of reactive nitrogen back to the snowpack. In order to consider the current model results in context of prior field work at Summit, we have compared model results with the diurnal variation in vertical gradients of $\mathrm{NO}_{\mathrm{x}}$ and $\mathrm{HNO}_{3}$ measured in the lower $2 \mathrm{~m}$ above the snowpack at Summit, Greenland, during summer 2000 (Honrath et al., 2002). Honrath and co-workers measured the diurnal cycle of the difference between $\mathrm{NO}_{\mathrm{x}}$ mixing ratios at 3.5 and $200 \mathrm{~cm}$ above the snow, resulting in a maximum difference during mid-day (representing a flux out of the snowpack). Because the first grid box in the model atmosphere is one meter in height, in order to compare with these vertical gradients, we calculated the gradient between the snow surface (upper most snow grid cell) and the concentration in the atmosphere at a height of $1.5 \mathrm{~m}$. The model predicts a midday peak in the vertical gradient of $\mathrm{NO}_{\mathrm{x}}$, at the same time as measured by Honrath and co-workers (Fig. 2b), showing the model agrees well with the measured diurnal cycle for $\mathrm{NO}_{\mathrm{x}}$.

The diurnal cycle of $\mathrm{HNO}_{3}$ was also measured using inlet heights of 2 and $200 \mathrm{~cm}$ by Honrath et al. (2002), with a maximum vertical gradient at mid-day (representing a flux towards the snow surface). We have computed corresponding vertical gradients in model using the same method described above for $\mathrm{NO}_{\mathrm{x}}$. The model predicts a small gradient of $\mathrm{HNO}_{3}$, representing a flux out of the snow during mid-day as well as a less significant uptake of $\mathrm{HNO}_{3}$ back to the snow at night. Gas phase production of $\mathrm{HNO}_{3}$ occurs in the interstitial air via the reaction of $\mathrm{NO}_{2}+\mathrm{OH}$ (Reaction R8) during mid-day due to elevated concentrations of both reactants.

$\mathrm{NO}_{2}+\mathrm{OH} \stackrel{\mathrm{M}}{\longrightarrow} \mathrm{HNO}_{3}$

Disagreement between the sign of the vertical gradient of $\mathrm{HNO}_{3}$ at mid-day between the model and measurement could be due an unknown input of atmospheric $\mathrm{HNO}_{3}$ from an external source, for example atmospheric transport to Summit during measurements made during summer of 2000 that was not present during 2008. The small values of the measured $\mathrm{HNO}_{3}$ vertical gradient could also be subject to experimental error. It is also likely we have included an incomplete description of LLL chemistry that results in overprediction of interstitial air $\mathrm{OH}$ and/or $\mathrm{NO}_{2}$ resulting in disagreement in the sign of the gradient. Large uncertainty in the initial nitrate concentration in the LLL is another potential source of of the disagreement. 


\subsection{BrO mixing ratios}

Contour plots of model predicted $\mathrm{BrO}$ mixing ratios in the atmosphere and interstitial air are shown in Fig. $7 a$ and $b$ respectively. Atmospheric $\mathrm{BrO}$ shows a similar diurnal variation as NO (Fig. 5) with maxima of 2-3 ppt in the morning and late evening. Model $\mathrm{BrO}$ is compared with measurements of $\mathrm{BrO}$ by chemical ionization mass spectrometry (CIMS) and long-path differential optical absorption spectroscopy (LP-DOAS) in panel $\mathrm{c}$ and predicted interstitial air mixing ratios are shown in panels $\mathrm{b}$ and $\mathrm{d}$. The model $\mathrm{BrO}$ generally agrees well with the observations within the uncertainty, although there are some differences during the first day of the model run, most likely due to the low initial gas phase reactive bromine mixing ratio in the interstitial air and atmosphere.

Atmospheric $\mathrm{BrO}$ mixing ratios in the model result from a small reactive halogen flux from bromine impurities in surface snow that undergo photochemistry and subsequent release from the snowpack (referred to as local production). Model predicted $\mathrm{BrO}$ in both interstitial air and the atmosphere is formed from photolysis of $\mathrm{Br}_{2}$ (Reaction R9) followed by reaction with ozone (Reaction R10).

$\mathrm{Br}_{2}(\mathrm{~g})+\mathrm{h} v \longrightarrow 2 \mathrm{Br}(\mathrm{g})$

$\mathrm{Br}(\mathrm{g})+\mathrm{O}_{3}(\mathrm{~g}) \longrightarrow \mathrm{BrO}(\mathrm{g})+\mathrm{O}_{2}(\mathrm{~g})$

Molecular bromine is formed via aqueous chemistry in the LLL by a series of reactions that begin with oxidation of the bromide ion (Reaction R11) to form $\mathrm{Br}_{2}$, followed by transfer of bromine from the LLL to the gas phase (Reaction R12).

$\mathrm{Br}^{-}(\mathrm{aq}) \longrightarrow \longrightarrow \rightarrow \frac{1}{2} \mathrm{Br}_{2}(\mathrm{aq})$

$\mathrm{Br}_{2}(\mathrm{aq}) \longrightarrow \mathrm{Br}_{2}(\mathrm{~g})$

Formation of $\mathrm{Br}_{2}$ in the LLL involves many steps and reaction pathways including reactions involving $\mathrm{Cl}^{-}, \mathrm{Br}^{-}, \mathrm{OH}$, $\mathrm{HOBr}$, and $\mathrm{H}^{+}$(see Supplement for a complete list of reactions). $\mathrm{OH}$ is important as an oxidant in the LLL to initiate bromine production via reaction of $\mathrm{OH}$ with $\mathrm{Br}^{-}$to form $\mathrm{HOBr}^{-}$. Conversion of bromide to $\mathrm{Br}_{2}$ in the LLL is facilitated by the presence of $\mathrm{Cl}^{-}$due to fast cycling between bromine and chlorine species (for example Reactions R13 and R14). However, the model does not predict significant amounts of $\mathrm{BrCl}$ in the interstitial air because the $\mathrm{Br}: \mathrm{Cl}$ ratio in the LLL is far in excess of that for sea water, therefore $\mathrm{BrCl}$ immediately reacts with bromine to form $\mathrm{Br}_{2} \mathrm{Cl}^{-}$ (Reaction R15) followed by decomposition to $\mathrm{Br}_{2}$ and $\mathrm{Cl}^{-}$ (Reaction R16). Molecular bromine formed in the LLL is transferred to the interstitial air (Reaction R12) where it can undergo gas phase photochemistry.
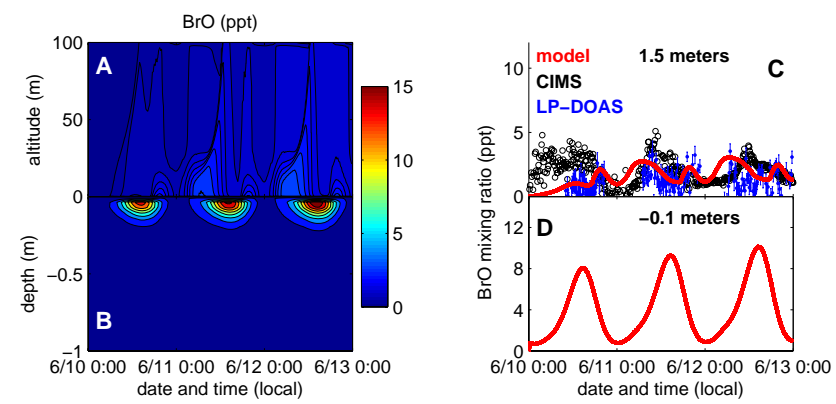

Fig. 7. Modeled $\mathrm{BrO}$ mixing ratios in the atmosphere (A) and interstitial (B) air. Modeled mixing ratios in tha atmosphere at an altitude of $1.5 \mathrm{~m}$ above the snowpack are compared with both CIMS and LP-DOAS measurements in panel (C). Predicted interstitial air mixing ratios $10 \mathrm{~cm}$ below the snow surface are shown in (D).

$$
\begin{gathered}
\mathrm{HOBr}(\mathrm{aq})+\mathrm{Cl}^{-}(\mathrm{aq})+\mathrm{H}^{+}(\mathrm{aq}) \longleftrightarrow \mathrm{BrCl}(\mathrm{aq}) \\
+\mathrm{H}_{2} \mathrm{O}(\mathrm{aq})
\end{gathered}
$$

$$
\begin{gathered}
\mathrm{HOCl}(\mathrm{aq})+\mathrm{Br}^{-}(\mathrm{aq})+\mathrm{H}^{+}(\mathrm{aq}) \longleftrightarrow \mathrm{BrCl}(\mathrm{aq}) \\
+\mathrm{H}_{2} \mathrm{O}(\mathrm{aq})
\end{gathered}
$$

$\mathrm{BrCl}(\mathrm{aq})+\mathrm{Br}^{-}(\mathrm{aq}) \longleftrightarrow \mathrm{Br}_{2} \mathrm{Cl}^{-}(\mathrm{aq})$

$\mathrm{Br}_{2} \mathrm{Cl}^{-}(\mathrm{aq}) \longleftrightarrow \mathrm{Br}_{2}(\mathrm{aq})+\mathrm{Cl}^{-}(\mathrm{aq})$

In order to understand the mechanism for bromine release from the LLL, we have conducted three test runs (1) with no initial chloride in the LLL, (2) initially neutral $\mathrm{pH}$ in the LLL, and (3) with the $\mathrm{Br}^{-}+\mathrm{OH}$ reaction rate equal zero. Runs 1 and 2 (not shown) predict a negligible amount of bromine release from the LLL. Run 3 (also not shown) predicts initially a reduction in $\mathrm{Br}_{2}$ by $50 \%$ with smaller reductions (both vary as function of depth) as the run progresses. The presence of bromide, chloride, acidity, as well an initial oxidant are all important for bromine release from the LLL. A similar halogen activation mechanism was originally suggested by Vogt et al. (1996) and subsequent studies on halogen activation in aerosols have shown the importance of these processes in $\mathrm{Br}_{2}$ and $\mathrm{BrCl}$ release from aerosols (e.g. Moldanová and Ljungström, 2001; Platt and Hönninger, 2003).

The bromide content of melted snow was measured as part of GSHOX at Summit (Dibb et al., 2010) and is known to be present in trace amounts in the remote snowpack. Bromide reacts with $\mathrm{OH}$ in the LLL formed from direct photolysis of $\mathrm{H}_{2} \mathrm{O}_{2}$ in the LLL (Reaction R17) and from photolysis of the nitrate ion (Reaction R1). 
$\mathrm{H}_{2} \mathrm{O}_{2}(\mathrm{aq})+\mathrm{h} v \longrightarrow 2 \mathrm{OH}(\mathrm{aq})$

The relative contribution of LLL OH from $\mathrm{H}_{2} \mathrm{O}_{2}$ is between $60-90 \%$ of the total $\mathrm{OH}$, with typical values of $85 \%$. The remainder is primarily formed from nitrate photolysis, with the exact percent depending on the depth in the snowpack.

Release of LLL $\mathrm{Br}_{2}$ also proceeds through the uptake of $\mathrm{HOBr}$ onto snow grains, which is formed in the gas phase via the reaction of $\mathrm{BrO}$ with the $\mathrm{HO}_{2}$ radical (Reaction R18).

$$
\mathrm{BrO}(\mathrm{g})+\mathrm{HO}_{2}(\mathrm{~g}) \longrightarrow \mathrm{HOBr}(\mathrm{g})+\mathrm{O}_{2}(\mathrm{~g})
$$

The gas phase $\mathrm{Br}_{2}$ levels can also be impacted by the self reaction of $\mathrm{BrO}$ to form molecular bromine. However, as the role of the $\mathrm{BrO}$ self reaction depends on the square of the $\mathrm{BrO}$ concentration, it is less important for the relatively low $\mathrm{BrO}$ mixing ratios in our model run.

In the interstitial air, where both elevated $\mathrm{BrO}$ and $\mathrm{NO}_{2}$ mixing ratios are predicted, the gas phase reaction to form $\mathrm{BrNO}_{3}$ proceeds rapidly (Reaction R7). A large portion of the total reactive gas phase bromine in the interstitial air is in the form of $\mathrm{BrNO}_{3}$, near the surface between 15-75\% of the total bromine is present as $\mathrm{BrNO}_{3}$ and deeper in the snowpack (where no photolysis occurs) close to $100 \%$ of the bromine is stored as $\mathrm{BrNO}_{3} \cdot \mathrm{Br}_{2}$ recycling through the gas phase reaction of $\mathrm{BrNO}_{3}$ with $\mathrm{Br}$ (Reaction R19) contributes between 40 and $50 \%$ of the total $\mathrm{Br}_{2}$ formation in interstitial air.

$\mathrm{Br}(\mathrm{g})+\mathrm{BrNO}_{3}(\mathrm{~g}) \longrightarrow \mathrm{Br}_{2}(\mathrm{~g})+\mathrm{NO}_{3}(\mathrm{~g})$

Three processes contribute to loss of $\mathrm{BrNO}_{3}$ in the interstitial air including conversion to $\mathrm{Br}_{2}$ (Reaction R19), photolysis, and upward mixing. Gas phase reactions involving $\mathrm{BrNO}_{3}$ are not a net source of bromine in interstitial air and only contribute to recycling of reactive bromine back to $\mathrm{Br}_{2}$.

$\mathrm{BrNO}_{3}$ plays an important role as a gas phase reservoir in the atmosphere as well. While during the day only a small fraction of the total bromine is stored as $\mathrm{BrNO}_{3}$ in ambient air (average $<10 \%$ ) at night this fraction increases up to $\sim 75 \%$ due to increased $\mathrm{NO}_{2}$ mixing ratios (see discussion above). It is not clear if surface reactions involving gas phase $\mathrm{BrNO}_{3}$ occur on the surface of ice, the importance of surface reactions involving $\mathrm{BrNO}_{3}$ will be investigated in the context of a model sensitivity study in a corresponding paper (Thomas et al., 2011).

Transport of gas phase reactive bromine out of the snowpack occurs through upward mixing of a number of gas phase species including $\mathrm{Br}_{2}, \mathrm{BrNO}_{3}$, and $\mathrm{BrO}$. The flux of bromine out of the snowpack peaks at solar noon, when photochemical production of $\mathrm{Br}_{2}$ in the LLL is the most rapid. Molecular bromine is responsible for $\sim 45 \%$ of the total bromine flux out of the snowpack at mid-day. $\mathrm{BrNO}_{3}$ also plays an important role in transporting reactive bromine out of the snowpack into the atmosphere. During the day $\mathrm{BrNO}_{3}$ transport contributes approximately $30 \%$ of the reactive bromine transported to the atmosphere, with a larger percent at night when the total flux is at a minimum. Once $\mathrm{BrNO}_{3}$ is in the atmosphere it is rapidly converted to $\mathrm{Br}_{2}$ (Reaction R19), $\mathrm{BrNO}_{3}$ does not form as rapidly in the atmosphere due to lower $\mathrm{NO}_{2}$ mixing ratios than in the interstitial air.

Atmospheric aerosol also plays an important role in bromine recycling despite the low total aerosol number concentrations. It is known that aerosol particles which are present at Summit can persist for some time above the snow surface (Ziemba et al., 2010). In order to investigate the role of aerosols in bromine cycling, we have completed a model run without atmospheric aerosol in the boundary layer. This run resulted in $30 \%$ less $\mathrm{BrO}$ predicted compared to Fig. 7c, (not shown). Further investigation of the role of aerosol in bromine recycling at Summit is clearly warranted.

The diurnal profile of $\mathrm{BrO}$, with peaks in the morning and early night, is similar to model predicted NO. As in the case of $\mathrm{NO}$, lower $\mathrm{BrO}$ concentrations are observed as near surface air is actively mixed and diluted during midday. To investigate the influence of local snowpack emissions on the diurnal cycle of $\mathrm{BrO}$ we have compared model predicted atmospheric mixing ratios to hourly averaged LPDOAS measured $\mathrm{BrO}$ mixing ratios selected for times during the 2008 campaign when FLEXPART emission sensitivities indicate the source region for air sampled at Summit is primarily emissions from the surface of the Greenland ice sheet (Fig. 8). Agreement between modeled and measured mixing ratios provides evidence that emissions from the surface of the Greenland ice sheet are the source of reactive gas phase halogens in the boundary layer, for a more detailed discussion see Thomas et al. (2011). Both the timing of the peaks as well as the absolute values of the mixing ratios are in good agreement. This provides strong evidence that local air masses are influenced by snowpack emissions of reactive bromine. Finally, it is important to note that the LLL in the snowpack is not significantly depleted in bromide during the three day model run, suggesting that bromine cycling resulting in at least 3 ppt of $\mathrm{BrO}$ can be sustained for longer time periods at Summit.

\section{$3.4 \mathrm{O}_{3}$ mixing ratios}

Predicted atmospheric and interstitial air ozone mixing ratios are shown in Fig. 9. The modeled and observed ozone mixing ratios show excellent agreement during the first $48 \mathrm{~h}$ of the model run. On the final day of our focus period a rapid increase followed by a decrease in the measured ozone was observed, corresponding to a change in wind direction as noted by (Stutz et al., 2011). This most likely indicates an air mass change. However, there is no corresponding change in the measured $\mathrm{NO}$ or $\mathrm{BrO}$ mixing ratios (see $\mathrm{NO}$ and $\mathrm{BrO}$ sections). FLEXPART emission sensitivities do not indicate 


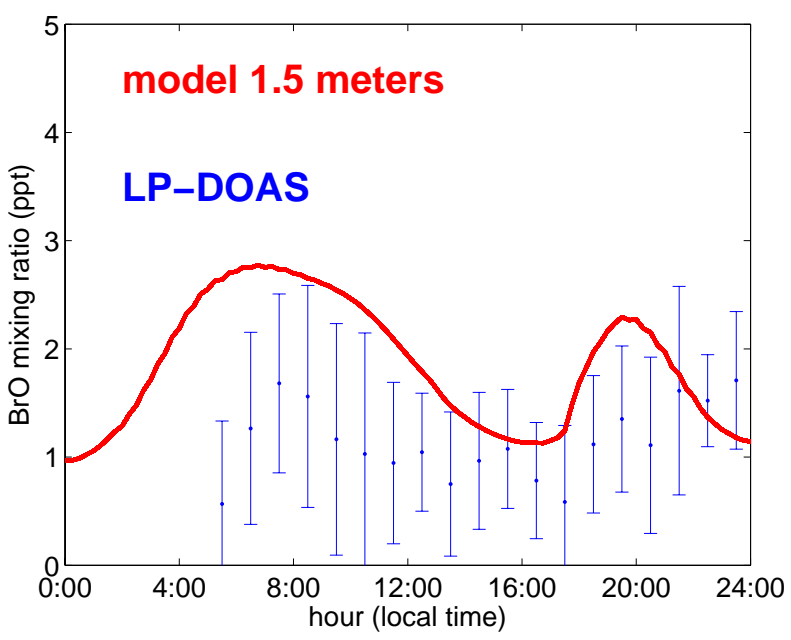

Fig. 8. Modeled $\mathrm{BrO}$ mixing ratios compared to the hourly averaged locally influenced $\mathrm{BrO}$ mixing ratios measured in air masses that have been over the ice sheet for at least 3 days before reaching Summit. Bars of the LP-DOAS data denote the variability of the data over the averaged days.

a significant change in the source region for air sampled during the time when increased ozone was observed. Our model does not include the effect of an air mass change, but any change that occurred would only impact the final day of our model run.

The model run predicts lower ozone in the snowpack than in ambient air. However ozone loss in the snowpack does not match the almost complete ozone destruction previously reported by Peterson and Honrath (2001). Very near the surface there is ozone production in the interstitial air at mid-day due to the high $\mathrm{NO}_{\mathrm{x}}$ concentrations. At night, when there is lower $\mathrm{NO}_{\mathrm{x}}$, there is ozone destruction near the snow surface. Specifically, at mid-day there is $\sim 2 \%$ more ozone at the surface of the snowpack than at a height of $1.5 \mathrm{~m}$ in the boundary layer. At night, there is $\sim 2 \%$ less ozone at the snow surface than in the boundary layer. Deeper in the snow pack, ozone concentrations are always lower than in the boundary layer due to the initial ozone gradient in the firn. The lack of complete ozone destruction can be explained by a combination of factors including only a moderate amount of $\mathrm{BrO}$ predicted in interstitial air $(<15 \mathrm{ppt} \mathrm{BrO})$, resulting in slower ozone destruction than occurs during typical ozone depletion events in the Arctic. Second, elevated hydroperoxyl radical concentrations in the interstitial air are predicted by the model (compared to ambient air). Consequently, there is ozone production through $\mathrm{NO}$ conversion to $\mathrm{NO}_{2}$ via the reaction with the hydroperoxyl radical. Third, fast downward mixing of ozone via mixing process from the overlying atmosphere results in replenishment of any ozone destroyed through gas phase bromine cycling in the firn air (in the current model run).
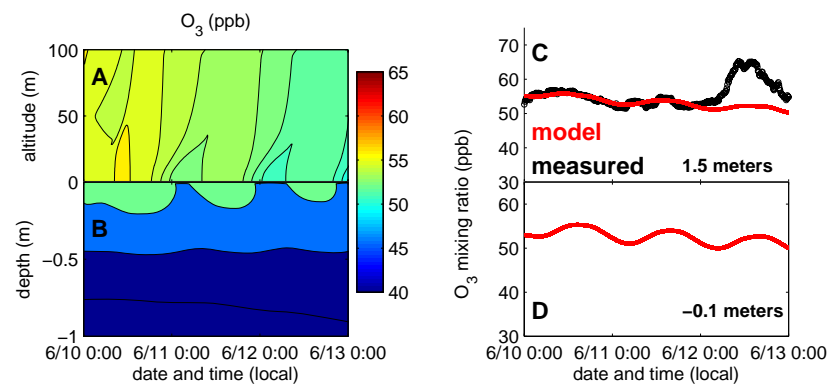

Fig. 9. Modeled $\mathrm{O}_{3}$ mixing ratios in the atmosphere (A) and interstitial (B) air. Modeled mixing ratios in the atmosphere at an altitude of $1.5 \mathrm{~m}$ above the snowpack are compared with measurements in (C). Predicted interstitial air mixing ratios $10 \mathrm{~cm}$ below the snow surface are shown in (D).

Although this model run does not predict significantly depleted ozone mixing ratios in interstitial air, halogen chemistry is still a likely cause of reduced ozone mixing ratios that have been measured in interstitial air (see for example Peterson and Honrath, 2001). A delicate balance of many factors including interstitial air reactive bromine mixing ratios, bromide content in the snowpack, replenishment of ozone from the overlying atmosphere, $\mathrm{NO}_{\mathrm{x}}$ mixing ratios, as well as the amount of $\mathrm{HO}_{\mathrm{x}}$ present in the firn air all have a role in determining ozone concentrations. Rapid destruction of ozone by bromine in the interstitial air could potentially occur under different conditions than observed during the 2008 focus period.

\section{Conclusions}

A one dimensional air/snow multiph ase chemical transport model (MISTRA-SNOW) was developed to simulate the vertical and temporal evolution of atmospheric chemistry at Summit, Greenland, and to test our understanding of sunlit snow as a chemical reactor. During periods when air masses were predominantly influenced by local chemistry, characterized by residence times on the Greenland ice sheet of at least 3 days, combined with stable diurnal meteorological conditions the model provides an excellent description of the observed $\mathrm{NO}$ and $\mathrm{BrO}$ mixing ratios and their diurnal profiles. The specific trends present in both the model and observations during the three day focus period are likely to be observed when there is a stable boundary layer at night, rapid venting during the day, and when an air mass has resided over the Greenland ice sheet for some time. A number of important mechanisms were identified to play a crucial role for the accurate description of boundary layer composition over sunlit snow: 
- During the three day focus period in 2008 both the model and measurements show that the atmospheric boundary layer exhibits a distinct diurnal behavior, with strong and shallow temperature inversions at night and in the early morning, and rapid mixing in the late morning to noon. The model, as well as field observations, clearly show that the boundary layer height is one of the main factors modulating surface trace gas mixing ratios over sunlit snow.

- Gas exchange processes including wind pumping and diffusion determine vertical redistribution of gases in the snowpack and impact the upward flux out of the snow. In our present model run, the effect of wind pumping dominates over gas diffusion at the surface of the snowpack, whereas gas diffusion dominates deeper in the snowpack. Considerable uncertainties in the representation of wind pumping in the model remain and further studies are required to improve its description.

- Solar actinic flux is the main driver of nitrogen oxide and reactive bromine release from the LLL. The accurate description of this parameter requires detailed knowledge of the penetration of actinic flux into the snowpack.

- Aqueous photochemistry in a LLL on the snow grains yields a reasonable description of the release of nitrogen oxides and reactive bromine. Nitrate photolysis was the main driver of $\mathrm{NO}_{\mathrm{x}}$ release, while a complicated reaction pathway leads to oxidation of bromide to $\mathrm{Br}_{2}$ and results in release from the LLL. $\mathrm{Br}_{2}$ release from the LLL depends on the concentration of LLL OH which, in our model, is formed through the photolysis of $\mathrm{H}_{2} \mathrm{O}_{2}$ and nitrate. A number of assumptions were made to describe the LLL including thickness $(10 \mathrm{~nm})$ and initial ion concentrations ( $6 \%$ of total nitrate and $100 \%$ of bromide and chloride measured in melted snow) in the LLL. We will investigate the sensitivity of the model results to these parameters in a companion paper (Thomas et al., 2011). Additional research on the physical and chemical properties of the LLL is imperative to further constrain these parameters.

Our results show that a model describing these mechanisms based on first principles can, despite the uncertainties in the physical and chemical processes, correctly describe coupled snow - atmosphere chemistry. Additional data, such as a new mechanism for nitrate photochemistry in snow developed by Bock and Jacobi (2010), will help to improve the existing model. New laboratory studies that study mechanisms for release of gas phase species from ice (for example Hellebust et al., 2010) and their influence on results will be evaluated in future work. The current model does not include chemistry on atmospheric ice particles during nocturnal fog events (observed during the focus period) and during blowing snow (not observed during the focus period), which can potentially influence atmospheric chemistry of $\mathrm{NO}_{\mathrm{x}}$ and reactive bromine. Mercury chemistry and its link to reactive halogens are currently also missing in the model. Further improvements in the model will address these and other issues to improve our knowledge of snow photochemistry. Direct comparison of the model results with measured interstitial air mixing ratios would also provide a needed constraint on snowpack chemistry, with the understanding that even small perturbations to vertical mixing at the snow surface could impact the ability to compare directly model results and measurements taken in this region. Continued efforts to characterize the chemical composition of interstitial air are essential. Sensitivity studies as well as a discussion of HONO, $\mathrm{H}_{2} \mathrm{O}_{2}$ and $\mathrm{HO}_{\mathrm{x}}$ chemistry using the current model version will be presented in a companion paper in this issue (Thomas et al., 2011) to further the goal of understanding the significance of sunlit snow as a chemical reactor and its impact on atmospheric chemistry.

\section{Supplementary material related to this article is available online at: http://www.atmos-chem-phys.net/11/4899/2011/ acp-11-4899-2011-supplement.pdf.}

Acknowledgements. The authors acknowledge J. Burkhart, D. Helmig, B. Seok, R. Honrath, Z. Courville, C. Anastasio, and P. Shepson for helpful discussions. The authors would like to thank all the members of the GSHOX campaign and the NSF GEO ATM Tropospheric Chemistry program for funding (Grant ATM0612279:002). Logistic support was provided by the NSF OPP Arctic Research Support and Logistics program and CH2MHill Polar Services. In addition, we extend thanks to the New York Air National Guard for the heavy airlift as well as thanks for permission to conduct research at Summit granted by the Danish Polar Center and Greenland Home Rule.

Edited by: U. Pöschl

\section{References}

Abbatt, J., Oldridge, N., Symington, A., Chukalovskiy, V., McWhinney, R. D., Sjostedt, S., and Cox, R. A.: Release of Gas-Phase Halogens by Photolytic Generation of $\mathrm{OH}$ in Frozen Halide-Nitrate Solutions: An Active Halogen Formation Mechanism?, J. Phys. Chem. A, 114, 6527-6533, 2010.

Albert, M. and Hawley, R.: Seasonal changes in snow surface roughness characteristics at Summit, Greenland: Implications for snow and firn ventilation, Ann. Glaciol., 35, 510-514, 2002.

Albert, M. and Shultz, E.: Snow and firn properties and air-snow transport processes at Summit, Greenland, Atmos. Environ., 36, 2789-2797, 2002.

George, I. J. and Anastasio, C.: Release of gaseous bromine from the photolysis of nitrate and hydrogen peroxide in simulated seasalt solutions, Atmos. Environ., 4, 543-553, 2007. 
Anderson, P. S. and Neff, W. D.: Boundary layer physics over snow and ice, Atmos. Chem. Phys., 8, 3563-3582, doi:10.5194/acp-83563-2008, 2008.

Atkinson, R., Baulch, D. L., Cox, R. A., Crowley, J. N., Hampson, R. F., Hynes, R. G., Jenkin, M. E., Kerr, J. A., Rossi, M. J., and Troe, J.: Summary of Evaluated Kinetic and Photochemical Data for Atmospheric Chemistry, Web Version, February 2006, available at: http://www.iupac-kinetic.ch.cam.ac.uk, 2006.

Barrie, L., Bottenheim, J., Schnell, R., Crutzen, P., and Rasmussen, R.: Ozone destruction and photochemical reactions at polar sunrise in the lower Arctic atmosphere, Nature, 334, 138-141, 1988.

Bock, J. and Jacobi, H. W.: Development of a mechanism for nitrate photochemistry in snow, J. Phys. Chem. A, 114, 1790-1796, doi:10.1021/jp909205e, 2010.

Boxe, C. S. and Saiz-Lopez, A.: Multiphase modeling of nitrate photochemistry in the quasi-liquid layer (QLL): implications for $\mathrm{NO}_{\mathrm{x}}$ release from the Arctic and coastal Antarctic snowpack, Atmos. Chem. Phys., 8, 4855-4864, doi:10.5194/acp-8-4855-2008, 2008.

Brooks, S., Moore, C., Lew, D., Lefer, B., Huey, G., and Tanner, D.: Temperature and sunlight controls of mercury oxidation and deposition atop the Greenland ice sheet, Atmos. Chem. Phys. Discuss., 11, 3663-3691, doi:10.5194/acpd-11-3663-2011, 2011.

Chameides, W. L.: The photochemistry of a remote marine stratiform cloud, J. Geophys. Res., 89, 4739-4755, 1984.

Chen, G., Huey, L. G., Crawford, J. H., Olson, J. R., Hutterli, M. A., Sjostedt, S., Tanner, D., Dibb, J., Lefer, B., Blake, N., Davis, D., and Stohl, A.: An assessment of the polar $\mathrm{HO}_{\mathrm{x}}$ photochemical budget based on 2003 Summit Greenland field observations, Atmos. Environ., 41, 7806-7820, doi:10.1016/j.atmosenv.2007.06.014, 2007.

Cho, H., Shepson, P. B., Barrie, L. A., Cowin, J. P., and Zaveri, R.: NMR Investigation of the Quasi-Brine Layer in Ice/Brine Mixtures, J. Phys. Chem. B, 106, 11226-11232, doi:10.1021/jp020449+, 2002.

Chu, L. and Anastasio, C.: Quantum yields of hydroxyl radical and nitrogen dioxide from the photolysis of nitrate on ice, J. Phys. Chem. A, 107, 9594-9602, doi:10.1021/jp0349132, 2003.

Conway, T., Lang, P., and Masarie, K.: Atmospheric Carbon Dioxide Dry Air Mole Fractions from the NOAA ESRL Carbon Cycle Cooperative Global Air Sampling Network, 1968-2008, available at: Path: ftp://ftp.cmdl.noaa.gov/ccg/co2/flask/month/, 2009.

Cunningham, J. and Waddington, E. D.: Snow physics as Air flow and dry deposition of non-sea salt sulfate in polar firn: paleoclimatic implications, Atmos. Environ., 27A, 2943-2956, 1993.

Davis, D., Nowak, J. B., Chen, G., Buhr, M., Arimoto, R., Hogan, A., Eisele, F., Mauldin, L., Tanner, D., Shetter, R., Lefer, B., and McMurry, P.: Unexpected High Levels of NO Observed at South Pole, Geophys. Res. Lett., 28, 3625-3628, doi:10.1029/2000GL012584, 2001.

Dibb, J., Arsenault, M., Peterson, M., and Honrath, R.: Fast nitrogen oxide photochemistry in Summit, Greenland snow, Atmos. Environ., 36, 2501-2511, doi:10.1016/S1352-2310(02)00130-9, 2002.

Dibb, J. E., Albert, M., Courville, Z., Anastasio, C., Galbavy, E. S., Atlas, E., Beyersdorf, A. J., Blake, D. R., Meinardi, S., Rowland, F. S., Swanson, A. L., Blake, N. J., Bocquet, F., Cohen, L., Helmig, D., Burkhart, J. F., Frey, M. M., Friel, D. K.,
Hutterli, M. A., Chen, G., Conway, T. J., and Oltrnans, S. J.: An overview of air-snow exchange at Summit, Greenland: Recent experiments and findings, Atmos. Environ., 41, 4995-5006, doi:10.1016/j.atmosenv.2006.12.006, 2007.

Dibb, J. E., Ziemba, L. D., Luxford, J., and Beckman, P.: Bromide and other ions in the snow, firn air, and atmospheric boundary layer at Summit during GSHOX, Atmos. Chem. Phys., 10, 99319942, doi:10.5194/acp-10-9931-2010, 2010.

Domine, F. and Shepson, P.: Air-snow interactions and atmospheric chemistry, Science, 297, 1506-1510, 2002.

Domine, F., Albert, M., Huthwelker, T., Jacobi, H.-W., Kokhanovsky, A. A., Lehning, M., Picard, G., and Simpson, W. R.: Snow physics as relevant to snow photochemistry, Atmos. Chem. Phys., 8, 171-208, doi:10.5194/acp-8-171-2008, 2008.

Foster, K. L., Plastridge, R. A., Bottenheim, J. W., Shepson, P. B., Finlayson-Pitts, B. J., and Spicer, C. W.: The Role of $\mathrm{Br}_{2}$ and $\mathrm{BrCl}$ in Surface Ozone Destruction at Polar Sunrise, Science, 291, 471-474, 2001.

Galbavy, E. S., Anastasio, C., Lefer, B., and Hall, S.: Light penetration in the snowpack at Summit, Greenland. Part 2 Nitrate photolysis, Atmos. Environ., 41, 5091-5100, doi:10.1016/j.atmosenv.2006.01.066, 2007.

Gombosi, T. I.: Gas Kinetic Theory, Cambridge University Press, 1994.

Grannas, A. M., Jones, A. E., Dibb, J., Ammann, M., Anastasio, C., Beine, H. J., Bergin, M., Bottenheim, J., Boxe, C. S., Carver, G., Chen, G., Crawford, J. H., Dominé, F., Frey, M. M., Guzmán, M. I., Heard, D. E., Helmig, D., Hoffmann, M. R., Honrath, R. E., Huey, L. G., Hutterli, M., Jacobi, H. W., Kln, P., Lefer, B., McConnell, J., Plane, J., Sander, R., Savarino, J., Shepson, P. B., Simpson, W. R., Sodeau, J. R., von Glasow, R., Weller, R., Wolff, E. W., and Zhu, T.: An overview of snow photochemistry: evidence, mechanisms and impacts, Atmos. Chem. Phys., 7, 4329-4373, doi:10.5194/acp-7-4329-2007, 2007.

Haman, C., Lefer, B., Dibb, J. E., and Clements, C.: Evidence for a mid- to upper-tropospheric source of bromide reaching Summit, Atmos. Chem. Phys. Discuss., in preparation, 2011.

Hausmann, M. and Platt, U.: Spectroscopic measurement of bromine oxide and ozone in the high Arctic during Polar Sunrise Experiment 1992, J. Geophys. Res., 99, 25399-25413, 1994.

Hellebust, S., O'Sullivan, D., and Sodeau, J. R.: Protonated Nitrosamide and Its Potential Role in the Release of HONO from Snow and Ice in the Dark, J. Phys. Chem. A, 114, 11632-11637, doi:10.1021/jp104327a, 2010.

Honrath, R. E., Peterson, M. C., Guo, S., Dibb, J. E., Shepson, P. B., and Campbell, B.: Evidence of $\mathrm{NO}_{\mathrm{x}}$ production Within or Upon Ice Particles in the Greenland Snowpack, Geophys. Res. Lett., 26, 695-698, 1999.

Honrath, R. E., Peterson, M. C., Dziobak, M. P., Dibb, J. E., Arsenault, M. A., and Green, S. A.: Release of $\mathrm{NO}_{\mathrm{x}}$ from Sunlightirradiated Midlatitude Snow, Geophys. Res. Lett., 27, 2237 2240, 2000.

Honrath, R., Lu, Y., Peterson, M., Dibb, J., Arsenault, M., Cullen, N., and Steffen, K.: Vertical fluxes of $\mathrm{NO}_{\mathrm{x}}, \mathrm{HONO}$, and $\mathrm{HNO}_{3}$ above the snowpack at Summit, Greenland, Atmos. Environ., 36, 2629-2640, doi:10.1016/S1352-2310(02)00132-2, 2002.

Hutterli, M., McConnell, J., Stewart, R., Jacobi, H.W., and Bales, R.: Impact of temperature-driven cycling of hydrogen peroxide $\left(\mathrm{H}_{2} \mathrm{O}_{2}\right)$ between air and snow on the planetary boundary layer, 
J. Geophys. Res., 106, 15395-15404, 2001.

Jacobi, H.W. and Hilker, B.: A mechanism for the photochemical transformation of nitrate in snow, J. Photochem. Photobio. A, 285, 371-382, 2007.

Jacobi, H.W., Bales, R., Honrath, R., Peterson, M., Dibb, J., Swanson, A., and Albert, M.: Reactive trace gases measured in the interstitial air of surface snow at Summit, Greenland, Atmos. Environ., 38, 1687-1697, doi:10.1016/j.atmosenv.2004.01.004, 2004.

Jones, A., Weller, R., Wolff, E., and Jacobi, H.W.: Speciation and rate of photochemical $\mathrm{NO}$ and $\mathrm{NO}_{2}$ production in Antarctic snow, Geophys. Res. Lett., 27, 345-348, 2000.

Jungwirth, P. and Tobias, D. J.: Molecular Structure of Salt Solutions: A New View of the Interface with Implications for Heterogeneous Atmospheric Chemistry, J. Phys. Chem. A, 105, 1046810472, 2001.

Jungwirth, P. and Tobias, D. J.: Ions at the Air/Water Interface, J. Phys. Chem. B, 106, 6361-6373, 2002.

Kahan, T. F., Reid, J. P., and Donaldson, D. J.: Spectroscopic Probes of the Quasi-Liquid Layer on Ice, J. Phys. Chem. A, 111, 1100611012, 2007.

Kaleschke, L., Richter, A., Burrows, J., Afe, O., Heygster, G., Notholt, J., Rankin, A., Roscoe, H., Hollwedel, J., Wagner, T., and Jacobi, H.W.: Frost flowers on sea ice as a source of sea salt and their influence on tropospheric halogen chemistry, Geophys. Res. Lett., 31, L16114, doi:10.1029/2004GL020655, 2004.

Kalnajs, L. and Avallone, L.: Frost flower influence on springtime boundary-layer ozone depletion events and atmospheric bromine levels, Geophys. Res. Lett., 33, L10810, doi:10.1029/2006GL025809, 2006.

King, M. and Simpson, W.: Extinction of UV radiation in Arctic snow at Alert, Canada $\left(82^{\circ} \mathrm{N}\right)$, J. Geophys. Res., 106, 12499 12507, 2001.

Křepelová, A., Newberg, J., Huthwelker, T., Bluhm, H., and Ammann, M.: The nature of nitrate at the ice surface studied by XPS and NEXAFS, Phys. Chem. Chem. Phys., 12, 8870-8880, 2010.

Kuo, M. H., Moussa, S. G., and McNeill, V. F.: Liquid-like layers on ice in the environment: bridging the quasi-liquid and brine layer paradigms, Atmos. Chem. Phys. Discuss., 11, 8145-8172, doi:10.5194/acpd-11-8145-2011, 2011.

Landgraf, J. and Crutzen, P.: An Efficient Method for ' On-Line' Calculations of Photolysis and Heating Rates, J. Atmos. Sci., 55, 863-878, 1998.

Liao, W. and Tan, D.: 1-D Air-snowpack modeling of atmospheric nitrous acid at South Pole during ANTCI 2003, Atmos. Chem. Phys., 8, 7087-7099, doi:10.5194/acp-8-7087-2008, 2008.

Liao, J., Huey, L. G., Tanner, D. J., Brooks, S., Dibb, J. E., Stutz, J., Thomas, J. L., Lefer, B., Haman, C., and Gorham, K.: Observations of hydroxyl and peroxy radicals and the impact of BrO at Summit, Greenland in 2007 and 2008, Atmos. Chem. Phys. Discuss., 11, 12725-12762, doi:10.5194/acpd-11-127252011, 2011.

Lind, J. A. and Kok, G. L.: Correction to "Henry's law determinations for aqueous solutions of hydrogen peroxide, methylhydroperoxide, and peroxyacetic acid" by John A. Lind and Gregory L. Kok, J. Geophys. Res., 99D, 21119, 1994.

List, R. J. (Ed.): Smithsonian Meteorological Tables, Smithsonian Institution Press, Washington DC, 6th edn., 1884.

Mefford, T.: Cooperative Institute for Research in Environmen- tal Sciences (CIRES), University of Colorado at Boulder, and NOAA Earth System Research Laboratory (ESRL), Boulder, Colorado USA, 2010.

Moldanová, J. and Ljungström, E.: Sea-salt aerosol chemistry in coastal areas. a model study, J. Geophys. Res., 106, 1271-1296, doi:10.1029/2000JD900462, 2001.

Mucha, M., Frigato, T., Levering, L. M., Allen, H. C., Tobias, D. J., Dang, L. X., and Jungwirth, P.: Unified Molecular Picture of the Surfaces of Aqueous Acid, Base, and Salt Solutions, J. Phys. Chem. B, 109, 7617-7623, 2005.

Peterson, M. C. and Honrath, R. E.: Observations of Rapid Photochemical Destruction of Ozone in Snowpack Interstitial Air, Geophys. Res. Lett., 28, 511-514, 2001.

Richards, N. K., Wingen, L. M., Callahan, K. M., Nishino, N., Kleinman, M. T., Tobias, D. J., and Finlayson-Pitts, B. J.: Nitrate ion photolysis in thin water films in the presence of bromide ions, J. Phys. Chem. A, doi:10.1021/jp109560j, in press, 2011.

Piot, M. and von Glasow, R.: The potential importance of frost flowers, recycling on snow, and open leads for ozone depletion events, Atmos. Chem. Phys., 8, 2437-2467, doi:10.5194/acp-82437-2008, 2008.

Platt, U. and Hönninger, G.: The role of halogen species in the troposphere, Chemosphere, 52, 325-338, 2003.

Rosenberg, R.: Why Is Ice Slippery?, Phys. Today, 58, 50-55, doi:10.1063/1.2169444, 2005.

Sander, R.: Modeling Atmospheric Chemistry: Interactions between Gas-Phase Species and Liquid Cloud/Aerosol Particles, Surv. Geophys., 20, 1-31, 1999a.

Sander, S. P., Friedl, R. R., Ravishankara, A. R., Golden, D. M., Kolb, C. E., Kurylo, M. J., Molina, M. J., Moortgat, G. K., Keller-Rudek, H., Finlayson-Pitts, B. J., Wine, P. H., Huie, R. E., and Orkin, V. L.: Chemical Kinetics and Photochemical Data for Use in Stratospheric Modeling, Tech. Rep. JPL Publication 06-2, Jet Propulsion Laboratory, Pasadena, CA, 2006.

Schwartz, S. E.: Mass-Transport Considerations Pertinent to Aqueous Phase Reactions of Gases in Liquid-Water Clouds, in: Chemistry of Multiphase Atmospheric Systems, edited by: Jaeschke, W., 415-471, NATO ASI Series, Vol. G6, 1986.

Simpson, W. R., Carlson, D., Hönninger, G., Douglas, T. A., Sturm, M., Perovich, D., and Platt, U.: First-year sea-ice contact predicts bromine monoxide $(\mathrm{BrO})$ levels at Barrow, Alaska better than potential frost flower contact, Atmos. Chem. Phys., 7, 621-627, doi:10.5194/acp-7-621-2007, 2007a.

Simpson, W. R., von Glasow, R., Riedel, K., Anderson, P., Ariya, P., Bottenheim, J., Burrows, J., Carpenter, L. J., Frieß, U., Goodsite, M. E., Heard, D., Hutterli, M., Jacobi, H.-W., Kaleschke, L., Neff, B., Plane, J., Platt, U., Richter, A., Roscoe, H., Sander, R., Shepson, P., Sodeau, J., Steffen, A., Wagner, T., and Wolff, E.: Halogens and their role in polar boundary-layer ozone depletion, Atmos. Chem. Phys., 7, 4375-4418, doi:10.5194/acp-74375-2007, 2007b.

Sjostedt, S. J., Huey, L. G., Tanner, D. J., Peischl, J., Chen, G., Dibb, J. E., Lefer, B., Hutterli, M. A., Beyersdorf, A. J., Blake, N. J., Blake, D. R., Sueper, D., Ryerson, T., Burkhart, J., and Stohl, A.: Observations of hydroxyl and the sum of peroxy radicals at Summit, Greenland during summer 2003, Atmos. Envirom., 41, 5122-5137, doi:10.1016/j.atmosenv.2006.06.065, 2007.

Stutz, J., Thomas, J. L., Hurlock, S. C., Schneider, M., von Glasow, R., Piot, M., Gorham, K., Burkhart, J. F., Ziemba, L., Dibb, J. 
E., and Lefer, B. L.: Longpath DOAS observations of surface $\mathrm{BrO}$ at Summit, Greenland, Atmos. Chem. Phys. Discuss., 11, 6707-6736, doi:10.5194/acpd-11-6707-2011, 2011.

Thomas, J. L., Roeselová, M., Dang, L. X., and Tobias, D. J.: Molecular Dynamics Simulations of the Solution - Air Interface of Aqueous Sodium Nitrate, J. Phys. Chem. A, 111, 3091-3098, 2007.

Thomas, J. L., Stutz, J., Dibb, J. E., Huey, L. G., Lefer, B., and von Glasow, R.: Modeling halogen chemistry in and above snow at Summit, Greenland - Part 2: Radical Chemistry and Sensitivity Studies, Atmos. Chem. Phys. Discuss., in preparation, 2011.

Vogt, R., Crutzen, P. J., and Sander, R.: A mechanism for halogen release from sea-salt aerosol in the remote marine boundary layer, Nature, 383, 327-330, 1996.

von Glasow, R. and Crutzen, P. J.: Model study of multiphase DMS oxidation with a focus on halogens, Atmos. Chem. Phys., 4, 589608, doi:10.5194/acp-4-589-2004, 2004.

von Glasow, R., Sander, R., Bott, A., and Crutzen, P. J.: Modeling halogen chemistry in the marine boundary layer. 2. Interactions with sulfur and cloud-covered MBL, J. Geophys. Res., 107, 4323, doi:10.1029/2001JD000943, 2002a. von Glasow, R., Sander, R., Bott, A., and Crutzen, P. J.: Modeling halogen chemistry in the marine boundary layer. 1. Cloud-free MBL, J. Geophys. Res., 107, 4341, doi:10.1029/2001JD000942, 2002b.

Vrbka, L. and Jungwirth, P.: Brine rejection from freezing salt solutions: A molecular dynamics study, Phys. Rev. Lett., 95, 148501, doi:10.1103/PhysRevLett.95.148501, 2005.

Zhao, T., Gong, S., Bottenheim, J., McConnell, J., Sander, R., Kaleschke, L., Richter, A., Kerkweg, A., Toyota, K., and Barrie, L.: A three-dimensional model study on the production of $\mathrm{BrO}$ and Arctic boundary layer ozone depletion, J. Geophys. Res., 113, D24304, doi:10.1029/2008JD010631, 2008.

Zhou, X., Beine, H. J., Honrath, R. E., Fuentes, J. D., Simpson, W., Shepson, P. B., and Bottenheim, J. W.: Snowpack Photochemical production of HONO: A Major Source of $\mathrm{OH}$ in the Arctic Boundary Layer in Springtime, Geophys. Res. Lett., 28, 40874090, 2001.

Ziemba, L. D., Dibb, J. E., Griffin, R. J., Huey, L. G., and Beckman, P.: Observations of particle growth at a remote, Arctic site, Atmos. Environ., 44, 1649-1657, doi:10.1016/j.atmosenv.2010.01.032, 2010. 